Systems Estimation of a Structural Model of Distribution and Demand in the US Economy

Robert A Blecker, Yun Kim and Michael Cauvel May 2020 


\title{
Systems Estimation of a Structural Model of Distribution and Demand in the US Economy
}

\author{
Robert A. Blecker, Michael Cauvel, and Yun Kim*
}

May 2020

\begin{abstract}
Empirical studies of income distribution and aggregate demand using a structural modeling approach typically find that demand is wage-led in most large, advanced economies. These studies have been criticized for estimating the individual equations for consumption, investment, and net exports separately, treating total output and the wage share as exogenous, which could lead to simultaneity bias. This paper corrects for such possible bias as well as common shocks to the equations by using systems GMM estimation applied to annual US data for 1963-2016. This paper is also the first to provide separate estimates of nonresidential and residential investment functions and to distinguish the effects of shocks to different underlying determinants of the wage share (unit labor costs and firms' monopoly power). Surprisingly, the GMM estimates imply that private-sector aggregate demand is more, rather than less, wage-led (or in some cases, less profit-led) compared with OLS estimates of identically specified models.
\end{abstract}

Keywords: Income distribution, wage-led demand, profit-led demand, US economy, systems estimation

JEL codes: E12, E25, N12, O51, C36

*The authors wish to thank Aaron Pacitti and Giancarlo Rella, as well as participants in conferences of the Forum for Macroeconomics and Macroeconomic Policy (FMM), Berlin, Germany, October 2019, International Confederation of Associations for Pluralism in Economics Conference (ICAPE), San Diego, CA, January 2020, and Eastern Economic Association (EEA), Boston, MA, February 2020, for comments on earlier drafts. Authors' affiliations and emails: Blecker: Department of Economics, American University, blecker@american.edu; Cauvel: Department of Economics, Ithaca College, mcauvel@ithaca.edu; Kim: Department of Economics, University of Massachusetts, Boston, Yun.Kim@umb.edu. 


\section{Introduction}

In response to growing inequality, policy makers in many countries today are debating the use of redistributive policies and their likely macroeconomic consequences. For example, Mexico and South Korea have recently legislated increases in their minimum wages. In the 2020 US presidential primaries, several Democratic candidates advocated raising taxes on wealthy households while redistributing the benefits to working-class and middle-class families. In this context, the question naturally arises as to how such redistributive measures would affect macroeconomic performance. While there are many dimensions to this question, in this paper we limit ourselves to one key aspect: the impact of reversing the recent decline in the labor ("wage") share ${ }^{1}$ of national income on aggregate demand and national income.

Figure 1 shows that the wage share has declined sharply since around 2000 in the US economy by three alternative measures, and has trended downward over a longer period (since the 1970s) according to two of them. The notable decrease after 2000 is associated with a slowdown in average US economic growth, which makes it plausible that this aspect of worsening inequality could be a contributing factor toward "secular stagnation" in the US economy (see Summers, 2015; Blecker, 2016a; Cynamon and Fazzari, 2017).

The existing empirical literature on the relationship between the functional distribution of income and aggregate demand in the short run is deeply divided, with results that largely align with the methodologies employed. Those who follow an aggregative approach by directly estimating relationship between the capacity utilization rate (ratio of actual to potential output) and the wage (or profit) share generally find evidence of profit-led demand and a profit-squeeze in distribution (increasing utilization raises the wage share) in the short

\footnotetext{
${ }^{1}$ The terms "wage share" and "labor share" are used interchangeably in this paper to mean total labor compensation as a percentage of national income for the whole economy, or as a percentage of value added for particular sectors like nonfarm business or nonfinancial corporations. Similarly, "profit share" refers to all capital income as a percentage of the same aggregates; we do not distinguish a theoretical equilibrium return to capital from oligopolistic rents, as is done in some neoclassical studies.
} 


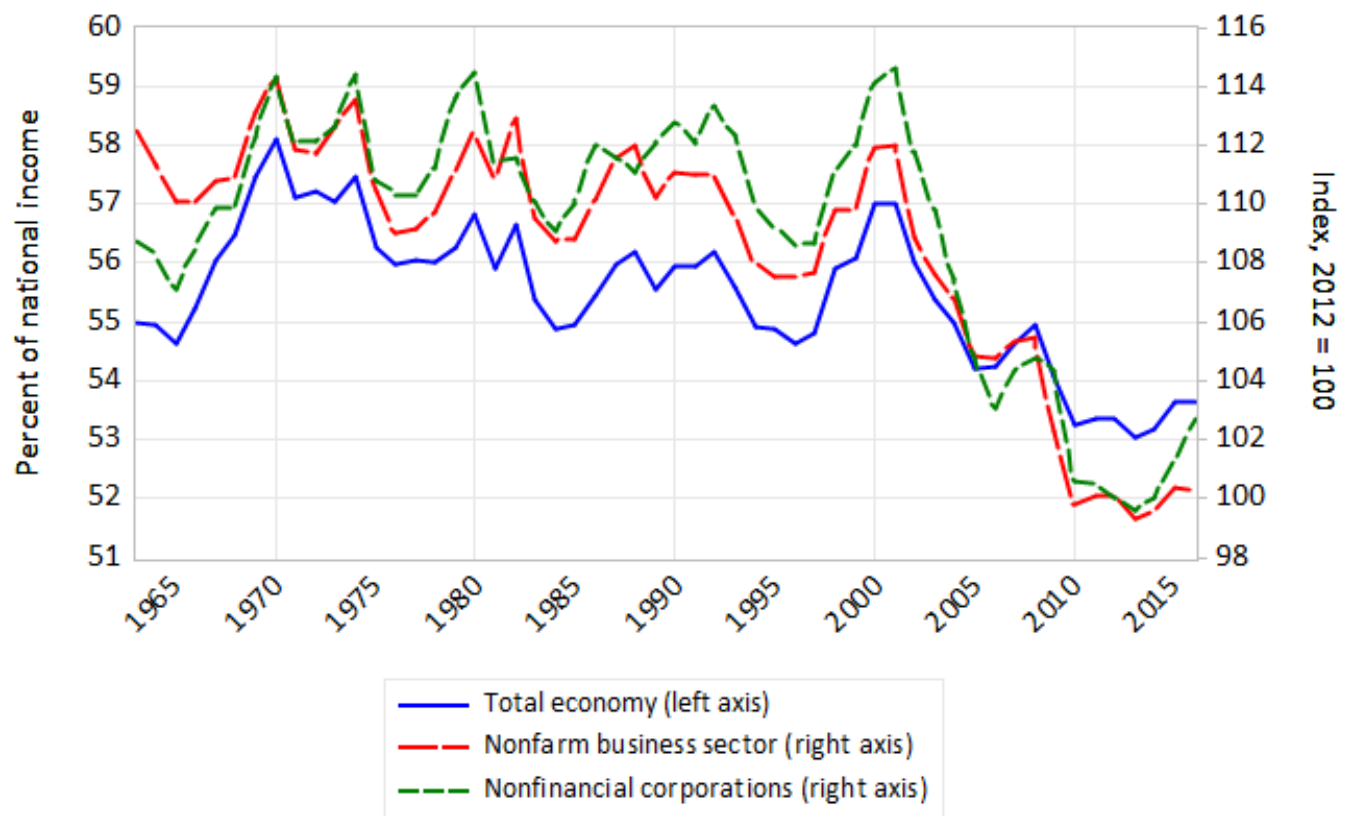

Figure 1: Three alternative measures of the US wage share, 1960-2017 Sources: US Bureau of Economic Analysis, US Bureau of Labor Statistics, and authors' calculations.

run (e.g., Barbosa-Filho and Taylor, 2006; Kiefer and Rada, 2015; Carvalho and Rezai, 2016). On the other hand, those who follow a structural approach by separately estimating the effects of the wage share on each component of aggregate demand (such as consumption and investment), while treating the wage share as exogenous, usually find evidence of wage-led demand in larger, more closed economies like the US, Germany, and the EU as a whole, but often find profit-led demand in smaller or more open economies like Austria, China, and Mexico (Hein and Vogel, 2008; Stockhammer et al., 2009, 2011; Onaran and Galanis, 2012; Stockhammer and Wildauer, 2016).

Much of the debate about these estimates has focused on whether the methodologies employed by one approach or the other may lead to biased results. On the one hand, Lavoie (2017) has suggested that the finding of profit-led demand in the aggregative studies may stem from failing to control for the procyclical effects of capacity utilization on labor 
productivity, an argument supported by the recent empirical findings of Cauvel (2019). On the other hand, critics of the structural studies fault them especially for treating the wage share as exogenous. Barrales and von Arnim (2017) report evidence of bi-directional Grangercausality between the utilization rate and the wage share, which implies that ignoring the effects of output on the wage share could result in simultaneity bias.

This paper contributes to the literature by testing the extent to which structural models are biased by failing to account for the systemic relationships between variables, including cross-equation correlation of the residuals in the presence of common shocks as well as the likely endogeneity of key right-hand side variables. To accomplish this, the paper compares estimates for a structural model obtained using the traditional method of estimating each equation separately to those found by estimating the same model as a system, using the generalized method of moments (GMM). The models are estimated for the US economy, which is a prime candidate for this exercise given the availability of sufficient data over a long historical period. Also, the fact that the US economy has been the subject of many previous studies on this topic helps to make the present results comparable to a large segment of the literature.

In addition, this paper makes several other contributions. First, this study uses a framework for estimating the relationship between demand and distribution that is more in line with theoretical models of open economies in the neo-Kaleckian tradition (Blecker, 1989), compared with previous empirical studies. Second, the paper distinguishes the impact of shocks to different underlying determinants of the wage share that operate through distinct channels and therefore have different effects on domestic demand and net exports. In this sense, the paper refines the concepts of "wage-led" and "profit-led" demand regimes to recognize that distributional effects on output may be specific to particular sources of variations in the wage share. Third, this paper estimates equations for the wage share and unit labor costs simultaneously with the usual demand functions (consumption, investment, 
exports, and imports). ${ }^{2}$ Fourth, this paper disaggregates total investment into nonresidential and residential investment, which are different variables that may respond in opposite ways to shifts in income distribution. ${ }^{3}$ Fifth, this paper is the first to use proxies for the monopoly power of firms in an empirical study of the distribution-demand nexus.

Surprisingly, this paper finds no evidence that the separate estimation of the structural equations or treatment of the wage share as exogenous biases the results toward finding more strongly wage-led demand. On the contrary, the systems GMM estimates consistently show that US private demand is more, not less, wage-led (or in some cases, less profit-led) compared with estimates of separate "single equations" for the components of aggregate demand. For shocks to monopoly power - for which two alternative proxies are used-US private demand is found to be wage-led using either type of estimation method, but more strongly so in the GMM results. For shocks to unit labor costs, the direction of the effects (wage-led versus profit-led) varies according to the time period considered, but overall demand is more wageled or less profit-led in the GMM estimates in all periods. Thus, there does not seem to be a systematic bias in single-equation estimates toward finding more wage-led results; in fact, the estimates reported here consistently show that the bias is in the other direction. That said, the quantitative results differ considerably depending on the source of the shock to distribution, the proxy used for firms' monopoly power, and the time period considered for shocks to unit labor costs.

The results reported here are also subject to other important qualifications and limitations. First, all of the estimates in this paper are concerned only with short-run relationships between distribution and demand; none of the results presented here relate to longer-term dynamics. Second, this paper considers only the broad "functional" distribution of income

\footnotetext{
${ }^{2}$ Other studies (e.g., Stockhammer, 2017a; Kohler et al., 2019) have examined the determinants of the wage share, but they have not incorporated a wage share equation into a broader structural macro model.

${ }^{3}$ To the authors' knowledge, only one previous study in this literature (Stockhammer et al., 2018) has differentiated between corporate and total investment, and none has estimated a separate equation for residential investment.
} 
between labor and capital, not other dimensions of inequality (for example, wage inequality between different types of workers or the distribution of income or wealth across households). Third, the paper only addresses whether the wage-led findings of most single-equation estimates for the US case are driven by simultaneity bias; it does not address other criticisms of this methodology. To enhance comparability with existing studies, this paper uses the method of adding up marginal effects of distributional shocks, which at best considers static effects ignoring possible dynamic feedbacks; alternative methodologies such as dynamic simulations or impulse responses are left for future research.

The rest of the paper is organized as follows. Section 2 discusses the relevant literature. Section 3 sketches out the theoretical model that motivates the empirical estimation. Section 4 briefly describes the econometric methods and data set employed, while section 5 summarizes the empirical results; details of the data set and estimated equations are given in appendices. Section 6 provides some concluding remarks.

\section{Literature Review}

The main theoretical framework for analyzing the relationship between the functional distribution of income and a measure of output (for example, the rate of growth or capacity utilization) has been the neo-Kaleckian approach (surveyed by Blecker, 2002; Hein, 2014; Lavoie, 2014; Blecker and Setterfield, 2019). In this framework, a redistribution of income toward labor is generally expected to stimulate consumption, for two reasons. First, workers are typically in lower income brackets than capital owners and hence tend to have a higher marginal propensity to consume. Second, firms typically retain a portion of their profits as corporate saving. On the other hand, investment - at least the corporate or business portion - is generally expected to be positively related to profitability (often measured by the profit share or profit rate). However, the demand for new housing is an important part of investment that, if anything, could be positively related to the level or share of wages- 
especially in a country like the US where homeownership is widespread. The net effect of a distributional shift toward wages on private domestic demand thus depends on whether the boost to household spending (consumption plus residential investment) outweighs the possible reduction in business investment. In an open economy, a redistribution toward wages associated with a rise in labor costs would be expected to reduce net exports, although this need not occur for a redistribution toward wages caused by a reduction in firms' monopoly power. The net effect of a redistribution toward labor on total private output then depends on the sum of the effects on private domestic demand and net exports.

What we have referred to as the "aggregative approach" ignores the underlying details about consumption, investment, and net exports, and instead estimates the effects of a measure of distribution on a measure of total output (for example, the utilization or growth rate). This approach has largely been defined by the "neo-Goodwin cycle" model of Barbosa-Filho and Taylor (2006), whose finding of profit-driven demand (a negative effect of the wage share on the utilization rate) and a profit-squeeze in distribution (positive impact of the utilization rate on the wage share) in US data spawned a whole new literature revolving around the idea of counterclockwise short-run cycles in utilization-wage-share space (see Nikiforos and Foley, 2012; Kiefer and Rada, 2015; Carvalho and Rezai, 2016). The advantage of the aggregative approach is that it naturally accommodates the simultaneous effects of distribution and demand on each other. However, critics have noted that the appearance of neo-Goodwin cycles in the data could result from other causal mechanisms besides profit-led demand and a profit-squeeze, such as the dynamics of Minskyan financial fragility or consumer debt accumulation, or the fact that the wage share varies countercyclically due to procyclical variations in labor productivity (see Stockhammer and Michell, 2016; Stockhammer, 2017b; Lavoie, 2017; Setterfield and Kim, 2017). ${ }^{4}$

\footnotetext{
${ }^{4}$ Blecker (2016b) observes that the profit-led demand findings at best pertain to short-run cyclical behavior, while Charpe et al. (2019) find empirically that US output growth is wage-led in the very long term but profit-led over shorter time horizons. Cauvel (2019) reports that the findings of profit-led demand and
} 
In contrast, what we have called the "structural approach" involves separately estimating functions for the individual components of private-sector aggregate demand to determine how each is affected by a redistribution of income. The distributional effects on each component are then added up to determine the total effect of a change in the functional distribution of income on aggregate demand. Most such studies treat government spending as exogenous and focus on the effects of the wage or profit share on private aggregate demand (the sum of consumption, investment, and net exports). ${ }^{5}$ Early studies in this vein reached mixed conclusions, often finding opposite results for the same countries, including the US (e.g., Bowles and Boyer, 1995; Gordon, 1995; Naastepad and Storm, 2006). However, all structural studies since around 2008 have found wage-led demand in the US and other large, advanced economies, like Germany and the EU as a whole, while often (but not always) finding profit-led demand in smaller and more open economies including Austria, Australia, Netherlands, Canada, Argentina, China, Mexico, and South Africa (see Hein and Vogel, 2008; Stockhammer et al., 2009, 2011; Onaran et al., 2011; Onaran and Galanis, 2012; Stockhammer and Wildauer, 2016; Onaran and Obst, 2016). ${ }^{6}$

Turning to the individual equations in a structural model, most studies (e.g., Naastepad and Storm, 2006; Hein and Vogel, 2008; Stockhammer et al., 2009, 2011; Onaran and Galanis, 2012; Onaran and Obst, 2016) regress consumption $(C)$ on total wages $(W)$ and profits $(R)$, along with any control variables (for example, household debt or net worth), to estimate the marginal propensities to consume (MPCs) out of wages and out of profits, $c_{W}$ and $c_{R}$,

a profit-squeeze in the short run disappear from the US data when one controls for the positive effect of output (utilization) on labor productivity, at least in some specifications.

${ }^{5}$ Some studies further limit their analysis to private domestic and do not consider exports and imports (for example, Stockhammer and Stehrer, 2011; Stockhammer et al., 2018).

${ }^{6}$ Some studies have also examined the impact of a simultaneous increase (or decrease) in the wage share in all countries in the sample on each individual country. For example, Onaran and Galanis (2012), Onaran and Obst (2016), and Obst et al. (2017) find that for some countries demand switches from profit-led to wage-led when a redistribution toward labor occurs simultaneously in their trading partners. 
respectively. Such estimates almost invariably find that the MPC out of wages is greater than the MPC out of profits. ${ }^{7}$

For investment, most structural studies have used versions of the function proposed by Bhaduri and Marglin (1990) and Marglin and Bhaduri (1990), in which investment (I, or its ratio to GDP, $I / Y$ ) is a function of a measure of income distribution (the profit or wage share) and an output variable (usually the GDP growth rate or capacity utilization rate) representing the accelerator effect, along with any control variables (e.g., Hein and Vogel, 2008; Naastepad and Storm, 2006; Onaran and Galanis, 2012; Stockhammer and Wildauer, 2016; Stockhammer and Stehrer, 2011; Stockhammer et al., 2018; Onaran and Obst, 2016). These studies almost uniformly find strongly positive and statistically significant accelerator effects. Empirical findings about distributional effects are much more varied, however, as the estimated coefficients on the distributional variable are frequently small and/or statistically insignificant. For the US, Naastepad and Storm (2006) found a significant positive effect of profitability, but that finding has not been replicated in later studies, such as Hein and Vogel (2008) and Onaran and Galanis (2012). ${ }^{8}$

The lack of robust evidence for positive profitability effects on total investment could indicate that distribution does not have a strong impact on investment, but there are other possible explanations. Most importantly, the weak estimated effects of the profit (or wage) share on total investment could be a result of the functional distribution of income having opposite effects on the two components of fixed investment, residential and nonresidential. The theories that predict a positive profitability effect are concerned only with the latter

\footnotetext{
${ }^{7}$ Some studies (see Onaran et al., 2011; Stockhammer and Stehrer, 2011; Stockhammer and Wildauer, 2016; Stockhammer et al., 2018) take a more direct approach to estimating the impact of distribution on consumption by including the wage (or profit) share along with national income or GDP $(Y)$ in the consumption equation. Onaran et al. (2011) disaggregate profits into rentier and non-rentier profit shares; they find that increases in either of these shares has a negative effect on consumption.

${ }^{8}$ Onaran et al. (2011) find evidence that firms' retained ("non-rentier") profits have a positive short-run effect on investment, while rentiers' profits have a negative long-run effect in some specifications. Stockhammer et al. (2018) find a positive effect of the wage share on total US investment and a negative effect on US corporate investment, but the statistical significance varies according to the specification.
} 
type of investment, not the former, but the former is a large share of total investment in many countries. In the US, residential investment averaged about one-quarter of total gross private fixed investment between 1960 and 2018. ${ }^{9}$ To investigate this issue further, this paper will disaggregate fixed investment into its residential and nonresidential components.

With regard to net exports, some early studies (Hein and Vogel, 2008; Stockhammer et al., 2009) used a simple approach of regressing this variable (measured as a ratio to GDP) directly on the profit (or wage) share, domestic and foreign income, and other variables. More recent studies (e.g., Stockhammer et al., 2011; Onaran et al., 2011; Onaran and Galanis, 2012; Obst et al., 2017; Onaran and Obst, 2016) have estimated separate equations for export and import demand as functions of relative prices of domestic and foreign goods as well as appropriate income variables (foreign for exports and domestic for imports) and control variables. These later studies usually estimate separate equations for domestic and export prices as functions of unit labor costs and other variables. ${ }^{10}$ These studies usually find the expected negative effects of the wage share (or unit labor costs) on exports, positive effects on imports, and/or negative effects on net exports, but the magnitudes of these effects and their statistical significance vary widely.

Although the stepwise process of estimating price functions along with export and import functions is more theoretically grounded than the simpler methods, the way that distribution is linked to trade in all these models seems theoretically ad hoc. This is most obvious for the studies that simply regress net exports on the wage or profit share. But even in the more complex models, unit labor costs are usually treated as a function of the wage share, whereas in a model that recognizes the endogeneity of the wage share the causality should be the reverse: the wage share should be a function of unit labor costs. In the next

\footnotetext{
${ }^{9}$ Authors' analysis of GDP data from US BEA, https://www.bea.gov/, accessed 28 September, 2019.

${ }^{10}$ Stockhammer and Wildauer (2016) estimate separate equations for exports and imports, but include the wage share directly in both equations, using panel data for 18 OECD countries. Naastepad and Storm (2006) found that real unit labor costs had a negative effect on export growth in all countries except the US, where they found a positive but insignificant effect; they did not estimate an import function.
} 
section, we will present a more theoretically consistent approach to modeling distributional effects on net exports.

Several studies have investigated the determinants of the labor (wage) share using a variety of empirical approaches. In the aggregative literature on neo-Goodwin cycles, most studies (e.g., Barbosa-Filho and Taylor, 2006; Kiefer and Rada, 2015; Carvalho and Rezai, 2016) have found evidence of a "profit-squeeze," in the sense that rising output (capacity utilization) drives up the wage share during the expansion phase of a business cycle, in both US and panel data. ${ }^{11}$ Stockhammer (2017a) found that financialization, globalization, and the decline of the welfare state were significant factors in explaining the decline of wage shares in a panel of OECD economies. Pariboni and Tridico (2019) found significant effects of financialization, globalization, deindustrialization, and changes in employment protection in another panel study. Kohler et al. (2019, p. 964) conclude that "International financial openness and financial payments of firms [viewed as part of firms' overhead costs] have the most robust negative impact on the wage share."

In a study of 59 countries using a neoclassical framework, Karabarbounis and Neiman (2014) found that falling labor shares could be attributed to falling relative prices of investment goods, which induce substitution of capital for labor. Elsby et al. (2013) found that falling wage shares in US industries were mainly driven by increasing import penetration and offshoring of labor-intensive activities, especially in manufacturing. De Loecker et al. (2020) find that average markups in large US firms increased sharply between the 1980s and 2016 and that these rising markups have contributed to the decreasing labor share. Autor et al. (2020) find that the falling US labor share was driven by increasing industrial concentration: as the firms that increased their market shares the most also had the highest profit shares, weighted-average profit shares naturally increased. Jayadev (2007) and Furceri and

\footnotetext{
${ }^{11}$ Nikiforos and Foley (2012) found a U-shaped distributional relationship, such that a rise in utilization reduces the wage share at low utilization rates but increases it at higher utilization rates, in US data.
} 
Loungani (2018) have found a negative effect of capital account liberalization on the labor share in international panel data.

The structural approach to estimating the distribution-demand relationship has a number of advantages, especially the ability to identify the effects of distribution on individual components of aggregate demand and hence to compare effects on (private) domestic demand and net exports (Blecker, 2016b; Onaran and Galanis, 2012; Onaran and Obst, 2016; Stockhammer, 2017b). However, the methodology used by previous structural studies also has some significant weaknesses. The primary criticism has been that the typical treatment of the wage (or profit) share as an exogenous variable could lead to simultaneity bias. The assumption of exogeneity is likely not accurate, as Stockhammer and Stehrer (2011) find that causality flows from both consumption and investment to the wage share in Granger-causality tests, while Barrales and von Arnim (2017) show that various measures of the output gap or utilization rate and the wage share Granger-cause each other. Similar problems could also arise from treating other variables as exogenous. For example, GDP is usually included in equations for investment and imports, but GDP includes investment and net exports (along with consumption and government purchases).

Some studies have tried to eliminate simultaneity bias by excluding contemporaneous effects of the wage (or profit) share from the estimated equations, and including only lagged distributional variables (for example, Naastepad and Storm, 2006; Stockhammer and Stehrer, 2011; Onaran et al., 2011). Although this addresses the endogeneity problem, it also loses information, thus creating potential misspecification bias by ignoring possibly significant contemporaneous effects of distribution on demand. In addition, the separate estimation of equations for different components of aggregate demand ignores common shocks, which can cause cross-equation correlation of the residuals. By itself, such correlation simply makes ordinary least squares (OLS) estimation inefficient, but in the presence of recursivity and simultaneity, it becomes another source of bias and inconsistency in OLS estimates. Another problem with the separate estimation of the equations in structural models is that it 
does not account for the systemic aspects of the models when "adding up" the marginal effects of distributional changes on the various components of aggregate demand, which ignores indirect distributional effects. For example, as Blecker (2016b) observed, estimated accelerator (output) effects on investment may partially reflect distributional effects on consumption (since consumption is about two-thirds of output), while estimated income effects on consumption could partially reflect distributional effects on investment (which determines income through the multiplier), but neither of these indirect effects would be included in standard estimates - which only capture direct effects of income distribution on the various components of aggregate demand. ${ }^{12}$

In this paper, we focus mainly on obtaining unbiased, consistent, and efficient parameter estimates in the presence of likely endogeneity and common shocks. To the best of the authors' knowledge, no structural study has yet attempted to overcome these problems by estimating a system of equations in which the functional distribution of income and the components of private aggregate demand are simultaneously determined and endogenous variables are instrumented by exogenous and lagged variables. This paper is intended to fill precisely that gap in the literature. For this purpose, the adding up of the estimated distributional coefficients actually enhances comparability with the previous literature; addressing the weaknesses of this method through alternative solution methods (for example, impulse responses) is left for future research. Nevertheless, there are considerable challenges involved in finding adequate instruments and ensuring that the model does not contain too many parameters to estimate compared with the sample size, as will be discussed below. First, we turn to the theoretical model that underlies our econometric estimates.

\footnotetext{
${ }^{12}$ Onaran and Obst (2016) have partially addressed this last concern by estimating indirect effects of the wage share on investment and net exports, but not on consumption.
} 


\section{Model}

The model presented in this section is not new or original theory; rather, it is an amalgam of elements from previous neo-Kaleckian models for open economies including those of Taylor (1983), Blecker (1989, 1999, 2011), and Bhaduri and Marglin (1990) in the theoretical domain and Stockhammer et al. (2011) and Onaran and Galanis (2012) in empirical studies, among many others. However, this is the first empirical paper that uses the approach to modeling an endogenous wage share and how it is linked to the real exchange rate (RER) and net exports originally developed by Blecker $(1989,2002)$ in a structural model of demand and distribution. Time subscripts are suppressed here to avoid cluttering the notation; lags will be introduced in later sections.

The model assumes an industrialized economy characterized by an oligopolistic market structure and excess capacity, so that prices are set by a gross markup $\tau>0$ over unit (average variable) costs and output is demand-driven in the short run. For simplicity (and because of data limitations), only unit labor costs are considered explicitly, so other costs must be reflected in (gross) markups. Unit labor costs $U L C$ can be written as the ratio of the nominal wage rate $w$ to labor productivity $y=Y / L$ (where $Y$ is output and $L$ is labor hours employed), so that the pricing equation for a representative firm is

$$
P=(1+\tau) \frac{w}{y}=(1+\tau) U L C
$$

In an open economy, firms adjust markups depending on the competitiveness of domestic goods relative to foreign goods: firms are able to increase markups when domestic goods are more competitive, and reduce ("squeeze") them when domestic goods are less competitive (to prevent too large a loss of market share). For mathematical convenience, this adjustment is modeled by assuming that the representative firm's markup factor or gross 
margin $(1+\tau)$ has a constant elasticity $\theta>0$ with respect to the RER:

$$
1+\tau=\mu\left(\frac{E P_{f}}{P}\right)^{\theta}
$$

where $E$ is the nominal exchange rate (in domestic currency per unit of foreign exchange), $P_{f}$ is the foreign price level, and $\mu>1$ represents the firm's target markup factor reflecting the monopoly power of firms as well as nonlabor costs.

It is easily seen that the profit share $\pi$ is positively related to the markup

$$
\pi=\frac{\tau}{1+\tau}
$$

while the wage share $\psi$ is inversely related to the markup, positively related to labor productivity, and equivalent to real unit labor costs:

$$
\psi=1-\pi=\frac{1}{1+\tau}=\frac{w / P}{y}=\frac{U L C}{P}
$$

Using the second of these expressions for $\psi$ and the pricing equation (1), the RER can be written as

$$
\frac{E P_{f}}{P}=z \psi
$$

where $z=E P_{f} /(w / y)$ is the ratio of the domestic-currency price of foreign goods $\left(E P_{f}\right)$ to nominal unit labor cost $(U L C=w / y)$. Hence, the $z$ ratio can be considered to reflect home country competitiveness. Then, substituting this equation for the RER into equation (2) and using (4) and the definition of $z$, we can solve for the (endogenous) wage share as a function of the target markup factor $\mu$ and the labor cost competitiveness ratio $z$ :

$$
\psi=\mu^{\frac{-1}{1+\theta}} z^{\frac{-\theta}{1+\theta}}
$$


so that increases in either $\mu$ or $z$ cause the wage share to decrease. To the authors' knowledge, this approach to modeling the relationship between unit labor costs, monopoly power, and the wage share has not been implemented previously in a structural econometric model. ${ }^{13}$

Next, we turn to the aggregate demand (income-expenditure) side of the model. First, we write the national income identity as

$$
Y=C+I_{r e s}+I_{n r}+G+X-M
$$

where $I_{r e s}$ is residential investment, $I_{n r}$ is nonresidential investment, $G$ is government purchases, $X$ is exports, and $M$ is imports, all measured in real terms (domestic goods or the equivalent for imports). In addition, we can specify the income side of the national accounts in real terms as follows:

$$
Y=W+R=(w / P) L+r K
$$

where $W=(w / P) L$ is total real labor ("wage") income, $r$ is the profit rate, $K$ is the capital stock, and $R=r K$ is total real capital ("profit") income. The real wage is $w / P=y /(1+\tau)$ and the profit rate is $r=(1-\psi)(Y / K)$. Depreciation of the capital stock is ignored, so that net and real magnitudes are the same for all relevant variables.

To ensure that the variables are stationary and to avoid heteroscedastic residuals, all variables are measured in first differences of natural logarithms (hereafter "log differences") in the regressions, and will be written here in that form for consistency. Consumption is specified as a function of wage and profit income:

$$
\Delta \ln C=\gamma_{C, W} \Delta \ln W+\gamma_{C, R} \Delta \ln R+\alpha_{\text {cons }} A_{\text {cons }}
$$

\footnotetext{
${ }^{13}$ Fernandez (2005) estimated an aggregative model using $z$ as a variable in the equation for the profit share, but did not include an empirical proxy for the target markup $\mu$, as we will below.
} 
where $\gamma_{C, W}$ and $\gamma_{C, R}$ are the elasticities of consumption with respect to wage and profit income (the corresponding marginal propensities will be defined below), $A_{\text {cons }}$ is a (column) vector of control variables (such as household wealth or debt ratios, also measured in log differences), and $\alpha_{\text {cons }}$ is the (row) vector of coefficients (elasticities) for the variables in $A_{\text {cons }}$. A constant is not included because any constant in the underlying relationship function in (log) levels would be eliminated by differencing. ${ }^{14}$

Following most of the structural literature, nonresidential (business or corporate) investment is modeled by a linearized Bhaduri-Marglin specification (Bhaduri and Marglin, 1990; Marglin and Bhaduri, 1990) with control variables $A_{n r}$ included, and again the variables are expressed in log differences:

$$
\Delta \ln I_{n r}=\gamma_{I n r, Y} \Delta \ln Y+\gamma_{I n r, \psi} \Delta \ln \psi+\alpha_{n r} A_{n r}
$$

where $\gamma_{I n r, Y}$ is the accelerator effect ${ }^{15}$ measured as an elasticity, and the distributional effect (elasticity with respect to the wage share, $\left.\gamma_{I n r, \psi}\right)$ is usually assumed to be negative. The control variables for nonresidential investment $A_{n r}$ could include, for example, a real interest rate or a measure of corporate debt.

Residential investment is modeled in parallel fashion as

$$
\Delta \ln I_{\text {res }}=\gamma_{\text {Ires }, Y} \Delta \ln Y+\gamma_{\text {Ires }, \psi} \Delta \ln \psi+\alpha_{\text {res }} A_{\text {res }}
$$

where we hypothesize that $\gamma_{\text {Ires }, \psi}$ is positive, assuming that homeownership is widely distributed among wage earners and the middle class (and even if workers rent their housing,

\footnotetext{
${ }^{14}$ Thus, if there is a statistically significant constant in any of the regression equations, it would reflect an exponential time trend because the variables are measured in log differences

${ }^{15}$ Theoretically, the accelerator principle states that the level (flow) of investment should be linked to the change (increase) in output, since net investment is the change in the capital stock and firms are assumed to increase their capital stocks in proportion to (expected) increases in the level of output. From that perspective, equation (10) is probably misspecified. However, this type of specification is common in neoKaleckian and Bhaduri-Marglin models, so we use it here for consistency with the previous literature.
} 
increased demand for rental units could also stimulate residential investment). The control variables for residential investment $A_{\text {res }}$ could include, for example, household debt, house prices, or the mortgage interest rate. Thus, the wage share is likely to have opposite effects on the two types of investment, which - if confirmed - could help to account for why it is often found to be insignificant in regressions for total investment.

Next, we turn to the open economy bloc of the model. Real home country exports $X$ are assumed to be imperfect substitutes for foreign goods, so they are a function of the relative price of foreign goods (i.e., the real exchange rate), and to be produced with infinitely elastic supplies, so their quantity is explained entirely by demand. Further assuming constant elasticities, the export demand function written in log difference form is

$$
\Delta \ln X=\varepsilon_{X}\left(\Delta \ln E+\Delta \ln P_{f}-\Delta \ln P\right)+\eta_{X} \Delta \ln Y_{f}
$$

where $\varepsilon_{X}>0$ is the relative price elasticity (in absolute value) and $\eta_{X}>0$ is the foreign income elasticity. Similarly, imports are imperfect substitutes for domestic goods and are assumed to have an infinite elasticity of supply in the world market, so their level is determined by the constant elasticity import demand function (again in log difference form)

$$
\Delta \ln M=-\varepsilon_{M}\left(\Delta \ln E+\Delta \ln P_{f}-\Delta \ln P\right)+\eta_{M} \Delta \ln Y
$$

where $\varepsilon_{M}>0$ and $\eta_{M}>0$ are the relative price and domestic income elasticities, respectively (again, the price elasticity is defined as the absolute value).

To express the demand for exports and imports as functions of the underlying determinants of the real exchange rate and income distribution ( $\mu$ and $z$ ), we begin by substituting equation (6) into (5), which yields

$$
\frac{E P_{f}}{P}=\left(\frac{z}{\mu}\right)^{\frac{1}{1+\theta}}
$$


or, in log differences,

$$
\Delta \ln E+\Delta \ln P_{f}-\Delta \ln P=\left(\frac{1}{1+\theta}\right)(\Delta \ln z-\Delta \ln \mu)
$$

Then, substituting this expression for the rate of change in the real exchange rate into equations (12) and (13), the export and import demand functions become

$$
\Delta \ln X=\varepsilon_{X}\left[\left(\frac{1}{1+\theta}\right)(\Delta \ln z-\Delta \ln \mu)\right]+\eta_{X} \Delta \ln Y_{f}
$$

and

$$
\Delta \ln M=-\varepsilon_{M}\left[\left(\frac{1}{1+\theta}\right)(\Delta \ln z-\Delta \ln \mu)\right]+\eta_{M} \Delta \ln Y
$$

Finally, equation (6) for the wage share can be rewritten in log differences as

$$
\Delta \ln \psi=-\left(\frac{1}{1+\theta}\right) \Delta \ln \mu-\left(\frac{\theta}{1+\theta}\right) \Delta \ln z
$$

Thus, demand for exports and imports can each be expressed as a function of three underlying variables: the labor cost competitiveness ratio $z$, the monopoly power of firms $\mu$, and foreign or domestic income $\left(Y_{f}\right.$ or $\left.Y\right)$. We expect labor cost competitiveness to have a positive effect on exports and a negative effect on imports, and the reverse for monopoly power. ${ }^{16}$ Also, $\Delta \ln z$ can be further decomposed into $\Delta \ln z=\Delta \ln \left(E P_{f}\right)-\Delta \ln (w / y)$, in other words, the difference between the rates of change in prices of foreign goods and nominal unit labor costs, both measured in domestic currency.

\footnotetext{
${ }^{16}$ However, this last prediction should be taken with caution, because if firms price-discriminate between domestic and foreign markets, the degree of monopoly may not have the same impact on export sales as it does for goods sold domestically. For example, firms that are highly monopolistic at home may charge lower prices on exports than they do domestically, as in the standard model of a price-discriminating monopolist.
} 
Finally, the change in unit labor costs is explained by the following (admittedly ad hoc) equation:

$$
\begin{aligned}
\Delta \ln U L C= & \gamma_{U L C, 0}+\gamma_{U L C, Y} \Delta \ln Y+\gamma_{U L C, \text { InflExp }} \text { InflExp } \\
& +\gamma_{U L C, \text { Union }} \Delta \ln U \text { nion }+\alpha_{1981} D_{1981-2016}
\end{aligned}
$$

where InflExp is the expected inflation rate (end of previous period), ${ }^{17}$ Union is a measure of union strike activity (used as a proxy for labor's bargaining power or labor militancy), and $D_{1981-2016}$ is a dummy variable that equals 1 for $1981-2016$ and 0 earlier (thus, $\alpha_{1981}$ reflects an intercept shift in 1981, while $\gamma_{U L C, 0}$ is the intercept). Essentially, this specification aims at capturing determinants of both the numerator and denominator of $U L C=w / y$ : faster output growth could make both the nominal wage and labor productivity rise faster; higher expected inflation would be likely to make nominal wages increase faster; greater union militancy could also allow worker to obtain greater nominal wage increases, and labor market institutions were more favorable to workers before the shift to a neo-liberal policy regime in the early 1980 s. $^{18}$

The need for the structural break is suggested by the data plot in Figure 2, which shows a sharp downward shift in the mean level of $\Delta \ln U L C$ after 1980. Since we could not find any measurable covariate that would account for this shift, and the RESET test indicated that the equation was misspecified without a structural break, we found it necessary to include this dummy variable in the $U L C$ equation; a Quandt-Andrews test confirmed that 1981 is the optimal year for the break.

\footnotetext{
${ }^{17}$ Following the methodology used by Pacitti (2015), adjustments were made because observations prior to 1993 reflected 14-months ahead forecasts rather than 12-months ahead. The authors would like to thank Aaron Pacitti for sharing his data and answering questions about his methodology.

${ }^{18}$ Note that the inclusion of $Y$ here is what makes the system of equations truly simultaneous, because it creates the causal chain that $Y \rightarrow U L C \rightarrow z \rightarrow \psi$, while $Y$ includes $C, I_{r e s}, I_{n r}, X$, and $M$, all of which are functions of either $\psi$ or $z(C$ is implicitly a function of $\psi$ via $W$ and $R$ ).
} 


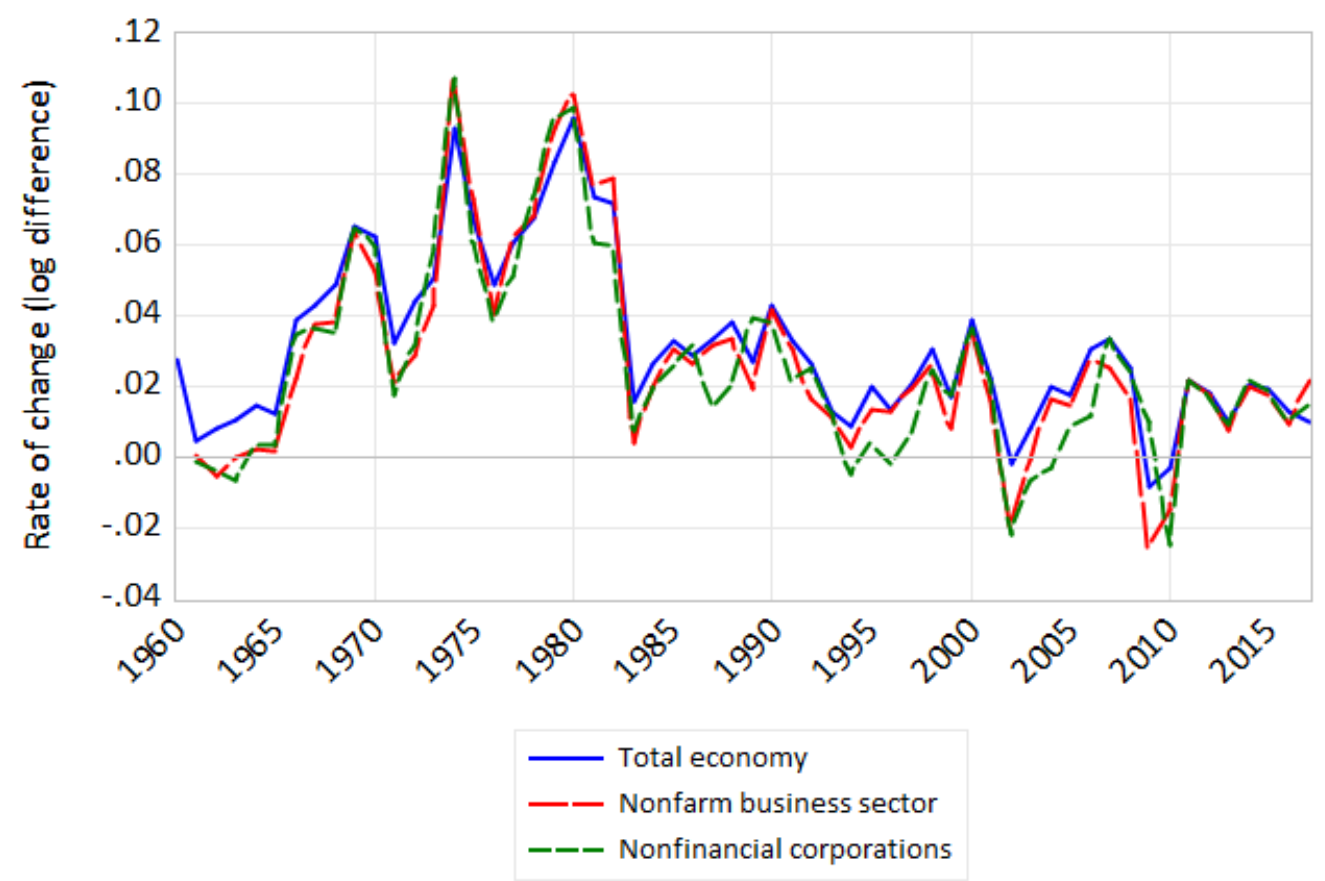

Figure 2: Annual rates of change in nominal unit labor costs, three alternative measures, 1960-2016

Sources: US Bureau of Economic Analysis, US Bureau of Labor Statistics, and authors' calculations.

Our strategy for estimating this model and computing the effects of a distributional shock on aggregate demand will be discussed in the next two sections.

\section{Empirical strategy and data set}

The econometric model consists of seven equations. Five of these are the functions for the components of private aggregate demand, $C, I_{n r}, I_{r e s}, X$, and $M$-essentially, all components of GDP except government purchases $G$ and inventory accumulation-based on equations (9)-(11) and (16)-(17). The two remaining equations, for the wage share $(\psi)$ and unit labor costs $(U L C=w / y)$, correspond to equations (18) and (19) in the theoretical model. All of these equations were modified by including lags, controls, and dummy variables as needed for econometric reasons explained below. 
Most of the variables are easily available from (or can be calculated from data provided by) the Bureau of Economic Analysis (BEA), Bureau of Labor Statistics (BLS), Federal Reserve (Fed), and other standard sources (see Appendix A, Table A.1, for details on variable definitions and sources). In cases where more than one measure could be used, we conducted extensive sensitivity tests to ensure that our results were not sensitive to the particular measure used. For example, although we use measures of $\psi$ and $U L C$ for the entire US economy in the estimates reported here, we found that using indexes of these variables for either the nonfarm business or nonfinancial corporate sector (shown in Figures 1 and 2) yielded qualitatively (and often quantitatively) similar results (in the OLS estimates).

However, for the monopoly power of firms - represented in the model by the firms' target markup rate $\mu$ in equation (2) - there are no standard indicators available. We therefore used two alternative proxies for monopoly power: a measure of the gross profit margin (GPM or $\left.\mu_{G P M}\right)$ for non-financial corporations and the weighted-average markup rate (AMR or $\mu_{A M R}$ ) for large US firms from De Loecker et al. (2020). GPM is defined as the ratio of the sum of unit corporate profits plus unit depreciation (consumption of fixed capital) to unit labor costs (compensation of employees) for the nonfinancial corporate domestic business sector from the BEA's national income accounts, which can be considered an accounting measure of the aggregate gross profitability of nonfinancial corporations. AMR is a measure of the markup over marginal costs as estimated by De Loecker et al. (2020), using what the authors call a "production approach," and is intended as a measure of "market power" in the US economy. Although earlier versions of these estimates have been subject to criticisms (for example, by Basu, 2019; Karabarbounis and Neiman, 2018), they are the only available estimates that have attempted to capture the average market power of US firms for a long enough time period for purposes of this study. ${ }^{19}$

\footnotetext{
${ }^{19}$ Although it may be confusing, the AMR is not intended to measure the aggregate markup rate $\tau$ in our model, but rather is used as a proxy for the underlying monopoly power of firms $\mu$ which is one of the determinants of $\tau$ (and of the wage share $\psi$ ).
} 
Our use of two alternative proxies for $\mu$ requires the estimation of two distinct models, which vary depending on which of these proxies is used but are otherwise equivalent; the estimation of these two alternative models constitutes an important sensitivity test for our findings. Since the main criticism of the De Loecker et al. (2020) markup estimates has been that they incorporate overhead costs into gross profits, thereby exaggerating the apparent degree of market power of firms, we include a control variable (the ratio of firms' selling, general and administrative costs to net sales revenue, hereafter referred to as SGA/Sales) representing overhead costs in our regressions using $\mu_{A M R}$.

As noted earlier, most of the variables are expressed as natural logarithms because the data series exhibit exponential time trends. The series in log levels were then tested for stationarity using three alternative unit root tests: augmented Dickey-Fuller, PhillipsPerron, and Kwiatkowski-Phillips-Schmidt-Shin. Since almost all of the series were found to be nonstationary in log levels and stationary in log differences ${ }^{20}$ by the vast majority of these tests, it was determined that nearly all had unit roots in log levels and therefore almost all of the variables were expressed in log differences. The only exceptions were inflation expectations and the real interest rate, which were already expressed as percentages (so they were not transformed into natural logs) and were found to be stationary in levels (so they were not differenced). ${ }^{21}$

To test whether treating the wage share and other income variables as exogenous and ignoring the systemic character of the model has biased previous structural estimates, we compare the results of models estimated using the same data sets, sample periods, and structural equations, but two alternative estimation strategies. First, the equations were estimated separately using OLS and treating the wage share and all income variables (total

\footnotetext{
${ }^{20} U L C$ was found to be stationary in log differences with an intercept break in 1981. Detailed results of the stationarity tests are available upon request.

${ }^{21}$ The long-run coefficient on the real interest rate was never significant in any equations and hence this variable was omitted from the estimates reported here.
} 
wages, profits, and GDP) as exogenous, as has traditionally been done in the structural literature surveyed above. Then, the same equations were estimated simultaneously using systems GMM, where income distribution (the wage share, as well as wage and profit income separately in the consumption function), total income $(Y)$, and other variables discussed below are treated as endogenous variables, while the exogenous variables and lags of the endogenous variables (also detailed below) are used as instruments.

In systems GMM, the parameters are estimated using moment conditions like those in equation (20), where $\boldsymbol{t}$ indexes time, the vector $\boldsymbol{Z}_{\boldsymbol{t}}$ denotes the set of all exogenous variables in the model, $v_{t j}$ is the error term for equation $j, y_{t j}$ is the dependent variable for equation $j, \boldsymbol{x}_{\boldsymbol{t} \boldsymbol{j}}^{\prime}$ is the (transposed) vector of independent variables for equation $j$, and $\boldsymbol{\beta}_{\boldsymbol{j}}$ is the corresponding coefficient vector (see Greene, 2011, Chapter 13): ${ }^{22}$

$$
E\left[\boldsymbol{Z}_{\boldsymbol{t}} v_{t j}\right]=E\left[\boldsymbol{Z}_{\boldsymbol{t}}\left(y_{t j}-\boldsymbol{x}_{\boldsymbol{t} \boldsymbol{j}}^{\prime} \boldsymbol{\beta}_{\boldsymbol{j}}\right)\right]=0
$$

In other words, the exogenous variables are assumed to be uncorrelated with the error term in each equation.

The GMM method comprises a class of estimators that encompasses other commonly used estimators such as linear and nonlinear least squares, instrumental variables, two- and three-stage least squares, and maximum likelihood estimators (Greene, 2011, Chapter 18). The GMM estimates are calculated using a two-step approach, in which parameter estimates are found using an initial weighting matrix, which is updated based on these parameter estimates. The updated weighting matrix is then used to obtain the final parameter estimates. The initial weighting matrix assumes that the moment equations are independent and identically distributed, while the updated weighting matrix assumes that the errors are homoscedastic and conditional on the instruments, but does not assume that the equations

\footnotetext{
${ }^{22}$ Note that the notation used in equation (20) is self-contained, that is, letters like $\boldsymbol{Z}, \boldsymbol{x}$, and $y$ do not have the same meanings that they have elsewhere in this paper.
} 
are independent. This method is well suited to address the problem of endogeneity, and hence provides an appropriate estimation method for our system emphasizing the interaction between endogenous variables.

All regression equations were initially specified as autoregressive distributed lag (ARDL) functions, meaning that lags of both the dependent and independent variables were included. To determine the optimal lag lengths, we used the Schwarz criterion (SIC) applied to the OLS estimates as a starting point. Initial specifications all included a constant, ${ }^{23}$ one lag of the dependent variable, ${ }^{24}$ and zero to two lags for each independent variable. We did not allow for longer lags because of our use of annual data, and also because the sample size is limited and the system will not be estimable by GMM (or the overidentifying restriction will not be satisfied) if the number of parameters is too large. We used SIC to select the lag lengths because it imposes a higher penalty for each additional parameter than other information criteria, such as Akaike, and therefore results in a model with fewer parameters.

For the most part, insignificant variables and lags were then dropped, to obtain more efficient estimates and to conserve degrees of freedom. However, in some cases, described in more detail in Appendix B, deviations from these initial lag lengths were made for any of the following three reasons: to improve the econometric properties of the OLS estimates (to satisfy the four diagnostic tests described below); to further reduce the number of parameters in order to increase the degrees of freedom for the system GMM estimates (help satisfy the overidentifying restriction); and/or for consistency with the theoretical model (keeping in variables that are theoretically indicated, so as to be able to test their significance). To further limit the number of parameters, the constant term was generally dropped from each equation, even if it was included by SIC, if it was statistically insignificant in the OLS

\footnotetext{
${ }^{23}$ It should be recalled that the constant terms (intercepts) in the underlying equations (in levels or $\log$ levels) are eliminated by differencing, so the constant in an equation specified in log differences represents an exponential time trend.

${ }^{24}$ The one exception is the equation for nonresidential investment, where we found it necessary to include two lags of the dependent variable to satisfy the diagnostic tests.
} 
estimates - unless it was necessary to keep the constant for the equation to pass certain diagnostic tests.

Each OLS regression equation was subject to a battery of diagnostic tests to ensure that it satisfies the necessary criteria-normality, homoscedasticity, and the absence of serial correlation of the residuals, as well as no misspecification bias-for the hypothesis tests to be statistically valid. The Jarque-Bera test was used to test for normality of the residuals. The Breusch-Pagan-Godfrey test was used to test for heteroscedasticity. The Breusch-Godfrey Lagrange multiplier test was used to test for serial correlation up to 2 lags. The Ramsey RESET test was conducted using both one and two fitted terms to test for possible misspecification error. For all equations, the tests fail to reject the null hypotheses of homoscedasticity, no serial correlation up to 2 lags, normality, and no specification error at the $10 \%$ level. In all cases, the same specification was used for each equation in both OLS and GMM for each model.

To determine whether there is cross-equation correlation of the residuals in the OLS estimates, we applied the Lagrange Multiplier (LM) test of Breusch and Pagan (1980) to the OLS residuals from each model. The Breusch-Pagan LM test statistic $\lambda$ is

$$
\lambda=n \sum_{i=2}^{m} \sum_{j=1}^{i-1} \rho_{i j}^{2}
$$

where $n$ is the number of observations, $m=7$ is the number of equations, $\rho_{i j}$ is the correlation coefficient between the residuals of equations $i$ and $j$, and $\lambda \sim \chi^{2}(0.5 m(1-m))$. The results (details available on request) show that the null hypothesis of no cross-equation residual correlation can be rejected at the $0.1 \%$ level for both models. This confirms the presence of common shocks, which make OLS estimates of the equations biased and inconsistent (as well as inefficient) given the simultaneity and recursivity in the system.

All regressions use annual data for the sample period 1963-2016, which was determined by data availability. Quarterly data were not used because they are not available for 
all variables, and using them could introduce complications such as seasonality that could distract from our focus on the distribution-demand relationship. At the front end, some of the data series begin in the early 1960s and are not available for earlier years; starting the regressions in 1963 allowed us to use up to two lags for all included variables but limited the number of extra lags we could use for a few of the instruments in GMM. At the back end, the AMR series from De Loecker et al. (2020) ends in 2016, so we did not attempt to extend the sample beyond that point.

For the GMM estimation, all the components of aggregate demand included in the model $\left(C, I_{n r}, I_{\text {res }}, X\right.$, and $\left.M\right)$ as well as all income and distributional variables $(Y, \psi, W$, and $R$ ) and unit labor costs $(U L C)$ are treated as endogenous. In addition, some of the control variables are treated as endogenous because they are likely to be affected by current incomes and expenditures. These include contemporaneous values of financial variables such as household net worth and corporate debt, both of which are measured at end-of-period levels (or, in log differences, rates of increase during a given period $t$ ). The manufacturing share of employment is treated as endogenous, because manufacturing employment is highly procyclical and the denominator of the ratio (total employment) is related to current GDP. We found that union strike activity is significantly related to GDP growth and the wage share, so that too was treated as endogenous. In contrast, inflation expectations were treated as exogenous because they are measured at the end of the previous period. Foreign income $\left(Y_{f}\right)$ and prices of foreign goods in US dollars $\left(E P_{f}\right)$ were also treated as exogenous. Since $U L C$ is endogenous, the ratio $z=E P_{f} / U L C$ is also endogenous.

The instruments for the GMM estimation include contemporaneous values of the exogenous variables as well as lags of the endogenous variables. For the seven endogenous variables that are explained by their own equations, only the lags actually included in the equations were used as instruments (this is no more than one lag in most cases, except for nonresidential investment for which it is two). For the other endogenous variables, up to four lags were included as instruments, depending on data availability and subject to 
not resulting in any instruments having to be dropped in the GMM procedure. ${ }^{25}$ Lists of the instruments used in each model along with the results of the Hansen $J$-tests for the overidentifying restrictions are given in Appendix A (Table A.2). Detailed econometric results for the estimation of the individual equations are discussed in Appendix B; the next section summarizes the implications of those results for the distribution-demand relationship.

\section{Results: marginal effects of shocks to income distri- bution}

As discussed earlier, we will evaluate the impact of distributional shifts by "adding up" the marginal effects of distributional shocks on the various components of (privatesector) aggregate demand. While we acknowledge the criticisms of this methodology cited earlier, this approach provides a convenient way of comparing our results with those of previous studies and assessing whether the use of single-equation estimation results in biased estimates (and, if so, in what direction). Unlike previous studies, however, we do not consider exogenous variations in the wage share per se, but instead consider shocks to two of its underlying determinants: the monopoly power of firms and unit labor costs. This is important because different drivers of changes in the wage share may have different effects on aggregate demand.

Since all the equations are estimated in log differences and the coefficients are therefore elasticities, they have to be weighted by appropriate ratios in order to be made additive. The equations for the total marginal effects of increases in $\mu$ and $U L C$, expressed as ratios

\footnotetext{
${ }^{25}$ Attempting to add more instruments only leads to the instruments becoming too collinear for the model to be solved, requiring some to be dropped.
} 
to $Y$, are as follows:

$$
\begin{aligned}
\left(\frac{\partial Y}{\partial \mu}\right) \frac{1}{Y}= & \left(\gamma_{C, W} \frac{C}{W}-\gamma_{C, R} \frac{C}{R}+\gamma_{I r e s, \psi} \frac{I_{r e s}}{W}+\gamma_{I n r, \psi} \frac{I_{n r}}{W}\right) \gamma_{\psi, \mu} \frac{\psi}{\mu} \\
& +\gamma_{X, \mu} \frac{X / Y}{\mu}-\gamma_{M, \mu} \frac{M / Y}{\mu}
\end{aligned}
$$

and

$$
\begin{aligned}
\left(\frac{\partial Y}{\partial U L C}\right) \frac{1}{Y}= & \left(\gamma_{C, W} \frac{C}{W}-\gamma_{C, R} \frac{C}{R}+\gamma_{\text {Ires }, \psi} \frac{I_{r e s}}{W}+\gamma_{I n r, \psi} \frac{I_{n r}}{W}\right) \gamma_{\psi, U L C} \frac{\psi}{U L C} \\
& +\gamma_{X, U L C} \frac{X / Y}{U L C}-\gamma_{M, U L C} \frac{M / Y}{U L C}
\end{aligned}
$$

where, as before, $\gamma_{i, j}$ is the elasticity of variable $i$ with respect to variable $j$, and all weighting factors (ratios) are evaluated at their sample means.

Table 1 summarizes the main results of these estimates; details of the estimation of the individual equations of the model are given in Appendix B (Tables B.1 to B.7), while the means of the ratios used to make the computations in equations (21) and (22) are given in Appendix A (Table A.3). The wage share effects shown here are the estimates of $\gamma_{\psi, \mu}(\psi / \mu)$ for shocks to monopoly power and $\gamma_{\psi, U L C}(\psi / U L C)$ for shocks to unit labor costs; the private demand effects are the total marginal effects from equations (21) and (22). Tables 2 and 3 present effects on the individual components of private demand (consumption, the two types of investment, and net exports), which add up to the total private demand effects shown in Table 1. For purposes of calculating the marginal effects, we use the "long-run coefficients" reported in Tables B.1 to B.7 along with the sample means of the weighting factors (ratios) and standard deviations of the shocks shown in Table A.3. To normalize the magnitudes of the marginal effects, we express them as the impact of a one standard deviation shock to either $\mu$ or $U L C$ (for the full sample period for $\mu$, and for each subperiod for $U L C$ ).

The marginal effects shown in Tables 1 to 3 reflect the corresponding portions of equation (21) or (22). For example, the marginal effect of a shock to $\mu_{G P M}$ on the wage share is given by $\gamma_{\psi, \mu}\left(\psi / \mu_{G P M}\right)$ and its effect on consumption is given by $\left[\gamma_{C, W}(C / W)-\right.$ 


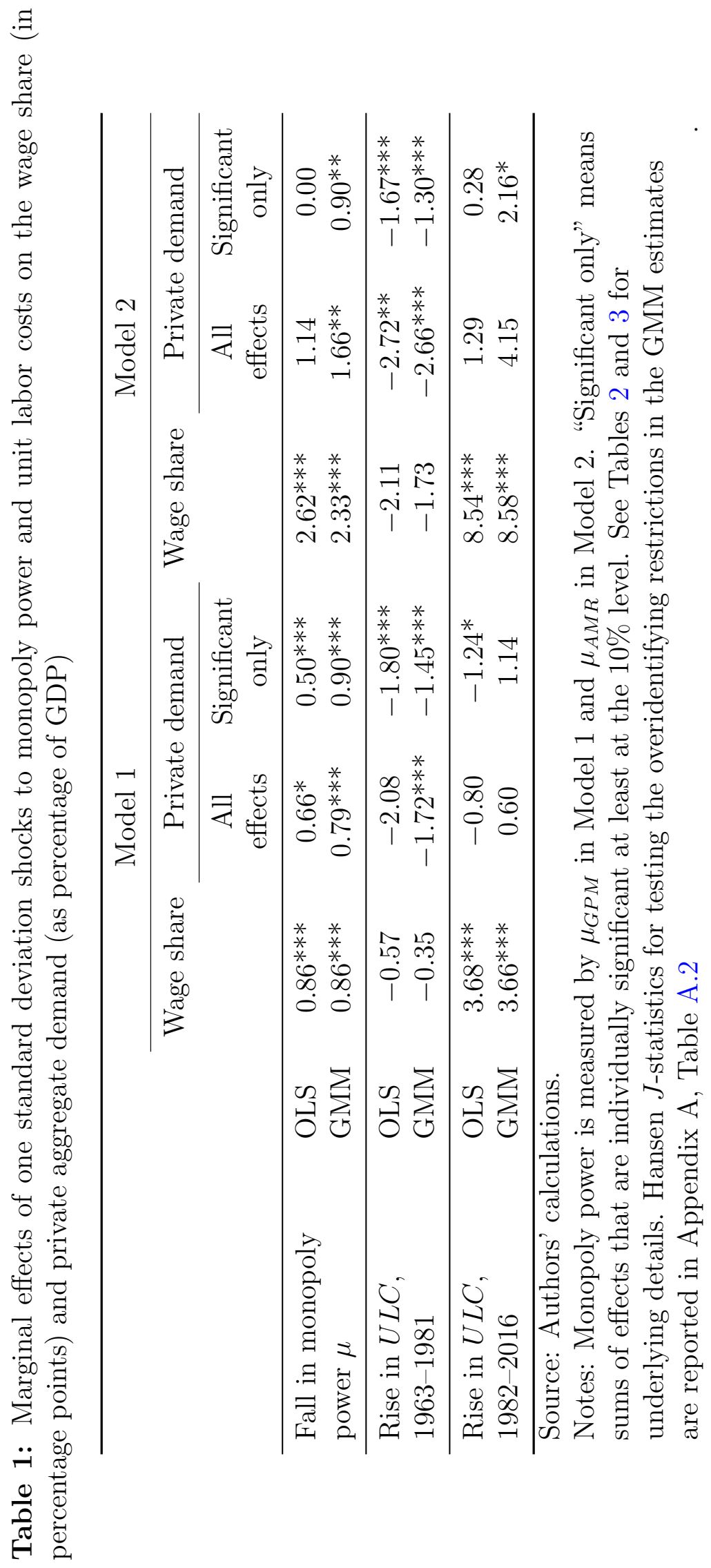


Table 2: Marginal effects of a one standard deviation decrease in monopoly power on private aggregate demand (in percent of GDP)

\begin{tabular}{lcccc}
\hline Model & \multicolumn{2}{c}{1} & \multicolumn{2}{c}{2} \\
\hline Estimation method & OLS & GMM & OLS & GMM \\
\hline$C / Y$ & $0.22^{*}$ & $0.27^{* *}$ & 0.67 & $0.90^{* *}$ \\
$I_{\text {res }} / Y$ & 0.33 & $0.45^{* *}$ & 1.01 & 1.10 \\
$I_{n r} / Y$ & -0.18 & -0.12 & -0.54 & -0.33 \\
$X / Y$ & $0.28^{*}$ & $0.18^{*}$ & 0.00 & 0.00 \\
$M / Y$ & 0.00 & 0.00 & 0.00 & 0.00 \\
\hline Using all estimated effects: & & & & \\
\hline Domestic & 0.37 & $0.60^{* *}$ & 1.14 & $1.66^{* *}$ \\
Net exports & $0.28^{*}$ & $0.18^{*}$ & 0.00 & 0.00 \\
Total private & $0.66^{*}$ & $0.79^{* * *}$ & 1.14 & $1.66^{* *}$ \\
\hline Using significant effects only: & \multicolumn{3}{c}{} \\
\hline Domestic & $0.22^{*}$ & $0.72^{* * *}$ & 0.00 & $0.90^{* *}$ \\
Net exports & $0.28^{*}$ & $0.18^{*}$ & 0.00 & 0.00 \\
Total private & $0.50^{* * *}$ & $0.90^{* * *}$ & 0.00 & $0.90^{* *}$ \\
\hline Source Anthors calcutions
\end{tabular}

Source: Authors' calculations.

Notes: Model 1 uses the gross profit margin $\left(\mu_{G P M}\right)$ as a proxy for monopoly power; Model 2 uses the average markup rate $\left(\mu_{A M R}\right)$ from De Loecker et al. (2020). All numbers are independently rounded.

$\left.\gamma_{C, R}(C / R)\right] \gamma_{\psi, \mu}\left(\psi / \mu_{G P M}\right)$, each multiplied by the standard deviation of $\mu_{G P M}$. The marginal effects on total private demand are the total sums shown in equation (21) or (22). Significance levels for all marginal effects were determined by chi-square tests applied to the null hypothesis that the corresponding effect (or sum of effects) equals zero.

In all three tables, "significant effects only" refers to sums of particular marginal effects (on consumption, residential investment, etc.) that are individually significant. These "significant only" sums are presented with caution, because the GMM procedure estimates all effects simultaneously using information on all equations, but are shown for comparison with previous studies that have often set individually insignificant effects to zero. Because of the structural break in 1982 for $U L C$ effects in the wage share equation (see Appendix B, 
Table B.7) ${ }^{26}$ we compute separate estimates of the marginal effects of shocks to $U L C$ for the subperiods 1963-1981 and 1982-2016, using the estimated coefficients, sample means, and standard deviations for those subperiods.

Thus, for example, in the first row of Table 1, the numbers for Model 1 should be interpreted as follows: a one standard deviation reduction in $\mu_{G P M}$ results in an 0.86 percent increase in the wage share and an 0.66 percent of GDP rise in total private demand using all estimated effects (or an 0.50 percent of GDP rise when only effects that are individually significant are included), in the OLS estimates. Because a fall in $\mu_{G P M}$ causes both the wage share and private demand to increase, we say that demand is "wage-led" in this case.

Before turning to the specific results, it is important to sound several notes of caution. First, our emphasis here is mainly on the qualitative results (signs and statistical significance of the estimated marginal effects), not the specific quantitative results. The magnitudes of the estimated impacts are sensitive to (among other things) the source of a shock to distribution (changes in monopoly power or unit labor costs), the proxy used for monopoly power (GPM in Model 1 and AMR in Model 2), and - for shocks to ULC - the subperiod considered. The quantitative results can thus be compared only across the two estimation methods (OLS and GMM) for the same model (1 or 2), the same shock (to $\mu$ or $U L C$ ), and (for $U L C$ ) the same time period; otherwise, the comparisons are not apples-to-apples. Second, these calculations of marginal effects on demand (both the individual components and the total impact) are really static exercises; we are literally computing the partial derivatives in equations (21) and (22) assuming everything else is held constant. So even though we add up all the individual effects, this procedure does not really capture overall dynamic effects. Third, the number of observations (54) is small relative to the number of parameters that are estimated in the systems GMM procedure (43 in Model 1 and 45 in Model 2); nevertheless,

\footnotetext{
${ }^{26}$ This break in the slope coefficient on $U L C$ in the wage share equation in 1982 should not be confused with the break in the intercept of the $U L C$ equation itself, which occurs in 1981 . The optimal years for all structural breaks were verified using Quandt-Andrews and Chow tests.
} 
the Hansen J-test for overidentifying restrictions is satisfied at the $10 \%$ level for each model (see bottom panel of Appendix Table A.2).

In Tables 1 and 2, shocks to monopoly power $\mu$ are presented as reductions in the two proxies, $\mu_{G P M}$ in Model 1 and $\mu_{A M R}$ in Model 2, so that they would be expected to increase the wage share. In fact, the estimated marginal effects of reductions in either of these proxies for firms' monopoly power on the wage share are positive and statistically significant at the $1 \%$ level, and these effects are similar between the OLS and GMM estimates for each model (Table 1). Furthermore, the total marginal effects on private demand are uniformly positive, indicating wage-led demand, across both models and regardless of whether OLS or GMM estimation is used. However, there is an important difference: for both models (i.e., both proxies for $\mu$ ), the positive effects on total private demand are greater and have higher levels of significance in the GMM estimates than in the corresponding OLS estimates.

The detailed estimates in Table 2 reveal the reasons for this finding: the GMM estimates imply greater positive marginal effects on consumption and residential investment, and smaller negative effects on nonresidential investment, compared with the OLS estimates for each model. This is true even for Model 2, in which the marginal effect of a reduction in $\mu_{A M R}$ on $\psi$ is somewhat smaller in the GMM estimates compared with OLS. According to the theoretical model, reductions in monopoly power are also expected to have positive effects on net exports because they make home goods relatively cheaper. However, the effect of the proxies for monopoly power on trade flows was significant only using $\mu_{G P M}$ in the export equation in Model 1 (see Appendix B, Table B.4), so the $\mu$ proxies were omitted from all other export and import equations and those effects were set to zero in Table 2. Overall, these results suggest that if there is any bias in the OLS ("single equation") estimates for shocks to monopoly power, it is in the direction of finding weaker wage-led demand effects.

For shocks to $U L C$, the direction of the marginal effects on the wage share varies dramatically between the two subperiods defined by the structural break in the wage share 
Table 3: Marginal effects of a one standard deviation increase in unit labor costs on private aggregate demand (in percent of GDP)

(a) Using long-run $U L C$ coefficient and standard deviation for 1963-1981

\begin{tabular}{lcccc}
\hline Model & \multicolumn{2}{c}{1} & \multicolumn{2}{c}{2} \\
\hline Estimation method & OLS & GMM & OLS & GMM \\
\hline$C / Y$ & -0.12 & -0.10 & -0.46 & -0.60 \\
$I_{\text {res }} / Y$ & -0.26 & -0.22 & -0.97 & -0.97 \\
$I_{n r} / Y$ & 0.10 & 0.04 & 0.37 & 0.21 \\
$X / Y$ & $-1.50^{* * *}$ & $-1.20^{* * *}$ & $-1.37^{* * *}$ & $-1.08^{* * *}$ \\
$M / Y$ & $0.30^{*}$ & $0.24^{*}$ & $0.30^{*}$ & 0.23 \\
\hline Using all estimated effects: & & & & \\
\hline Domestic & -0.28 & -0.27 & -1.05 & -1.36 \\
Net exports & $-1.80^{* * *}$ & $-1.45^{* * *}$ & $-1.67^{* * *}$ & $-1.30^{* * *}$ \\
Total private & $-2.08^{* * *}$ & $-1.72^{* * *}$ & $-2.72^{* *}$ & $-2.66^{* *}$ \\
\hline Using significant effects only: & & & & \\
\hline Domestic & 0.00 & 0.00 & 0.00 & 0.00 \\
Net exports & $-1.80^{* * *}$ & $-1.45^{* * *}$ & $-1.67^{* * *}$ & $-1.30^{* * *}$ \\
Total private & $-1.80^{* * *}$ & $-1.45^{* * *}$ & $-1.67^{* * *}$ & $-1.30^{* * *}$ \\
\hline
\end{tabular}

(b) Using long-run $U L C$ coefficient and standard deviation for 1982-2016

\begin{tabular}{lcccc}
\hline Model & \multicolumn{2}{c}{1} & \multicolumn{2}{c}{2} \\
\hline Estimation method & OLS & GMM & OLS & GMM \\
\hline$C / Y$ & $1.02^{*}$ & $1.24^{* *}$ & $2.37^{*}$ & $3.50^{* * *}$ \\
$I_{\text {res }} / Y$ & 1.26 & $1.72^{*}$ & 2.93 & 3.61 \\
$I_{n r} / Y$ & -0.82 & -0.54 & -1.91 & -1.33 \\
$X / Y$ & $-1.88^{* * *}$ & $-1.50^{* * *}$ & $-1.71^{* * *}$ & $-1.34^{* * *}$ \\
$M / Y$ & $0.38^{*}$ & $0.31^{*}$ & $0.38^{*}$ & 0.29 \\
\hline Using all estimated effects: & & & & \\
\hline Domestic & 1.46 & $2.42^{* *}$ & 3.39 & $5.79^{* *}$ \\
Net exports & $-2.26^{* * *}$ & $-1.82^{* * *}$ & $-2.09^{* * *}$ & $-1.64^{* * *}$ \\
Total private & -0.80 & 0.60 & 1.29 & 4.15 \\
\hline Using significant effects only: & \multicolumn{3}{c}{} \\
Domestic & $1.02^{*}$ & $2.96^{* *}$ & $2.37^{*}$ & $3.50^{* * *}$ \\
Net exports & $-2.26^{* * *}$ & $-1.82^{* * *}$ & $-2.09^{* * *}$ & $-1.34^{* * *}$ \\
Total private & $-1.24^{*}$ & 1.14 & 0.28 & $2.16^{*}$ \\
\hline Source Anthors & & &
\end{tabular}

Source: Authors' calculations.

Notes: Same as for Table 2. 
equation in 1982. As shown in Table 1, while increases in $U L C$ have the expected positive effects (significant at the 1\% level) on the wage share in the 1982-2016 subperiod, they have anomalously negative (but statistically insignificant) effects in 1963-1981. Although this is purely speculation, we suspect that the reason for the insignificant effects in the earlier subperiod is that firms were more able to fully pass through increases in $U L C$ into prices in the pre-globalization era. In any case, the anomalous signs on all of the marginal effects on domestic demand during the earlier subperiod (see panel (a) in Table 3) should be taken with great caution, since none of those effects are statistically significant. In contrast, the direct effects of shocks to $U L C$ on exports and imports have the expected signs (negative and positive, respective) in all estimates and are statistically significant in all but one case (imports in Model 2 in GMM). The negative effects on exports are particularly strong and significant at the $1 \%$ level in all estimates for both subperiods.

The results for the 1963-1981 subperiod can be interpreted as a case of "profit-led demand," in the sense that increases in unit labor costs cause total private demand to fall, but one has to be cautious in stating this conclusion because the impact on the wage share is insignificant, so there is no significant change in income distribution per se. In any event, the apparently profit-led results in this case stem entirely from the strong and significant impact on net exports. Also, in both models, the GMM estimates show that demand is less profit-led (in this sense) compared with the corresponding OLS estimates.

In the 1982-2016 subperiod, all the estimated marginal effects are more consistent with theoretical expectations: a positive shock to $U L C$ has a positive impact on the wage share, consumption, residential investment, and imports, and a negative impact on nonresidential investment and exports, in all estimates for both models (see panel (b) in Table 3). However, only the effects on the wage share, consumption, and exports are robust in terms of statistical significance; the effects on both types of investment are usually insignificant, while the effect on imports is small and significant only at the $10 \%$ level at best. Since the domestic effects are always positive overall while the net export effects are always nega- 
tive, the balance between these two determines whether total private demand is wage-led or profit-led. In Model 1, total private demand is profit-led in the OLS estimates but (weakly) wage-led in the GMM estimates, for this subperiod. For Model 2 in the same subperiod, overall demand is weakly wage-led in the OLS estimates and more strongly wage-led in the GMM estimates.

The reasons for the more wage-led results of the GMM estimates for the more recent time period (1982-2016) are clearly reflected in panel (b) of Table 3. In general, the GMM estimates find greater positive effects of shocks to $U L C$ on household expenditures (consumption and residential investment) and weaker negative effects on nonresidential investment, exports, and net exports, compared with the OLS estimates for the same model (1 or 2). Thus, controlling for simultaneity (the endogeneity of all the distributional and income variables) and common shocks leads to results that tilt more in the direction of wage-led demand effects of increased $U L C$, at least for the more recent period. In the earlier period (1963-1981), although demand appears profit-led in response to shocks to $U L C$, it is less profit-led in the GMM estimates than in the OLS ones. Thus, contrary to what has typically been expected, the single equation approach may actually underestimate the degree of wage-led demand or, similarly, overestimate the degree of profit-led demand.

As noted earlier, it is important to take the quantitative results reported here with caution. All of these estimates are sensitive to many aspects of the model specification, including not only whether distribution and income variables are treated as exogenous or endogenous, but also the precise forms of the various behavioral functions (lag structure, control variables, etc.), ${ }^{27}$ the proxy used for monopoly power of firms, and (for shocks to $U L C)$ the historical period considered. Indeed, some of the particular point estimates may

\footnotetext{
${ }^{27}$ In preparing this paper, the authors tried many other specifications of these functions before settling on the ones used here. In all of those experiments, almost invariably, the use of GMM estimation implied more wage-led (or less profit-led) marginal effects than OLS estimation of for the same model. This qualitative finding is thus not sensitive to varying functional forms for the behavioral equations of the model.
} 
be considered implausibly large. ${ }^{28}$ Thus, the magnitudes of the estimated effects need to be taken with considerable degrees of salt, but the qualitative finding that the systems GMM estimates indicate that demand is more wage-led (or less profit-led) than the single-equation OLS estimates is quite robust.

\section{Conclusions}

This paper is the first to apply systems GMM methods to estimating structural models of demand and distribution in order to control for simultaneity bias and the systemic dimension of multiequation models. In this approach, the wage share and other endogenous variables are instrumented by a set of exogenous or predetermined (lagged) variables. In addition, the paper also includes several new features in a structural model, including the disaggregation of fixed investment into its residential and nonresidential components, modeling the wage share as a function of unit labor costs (instead of the reverse), and re-specifying export and import demand as functions of labor cost competitiveness in line with the underlying theory. Furthermore, this is the first paper that distinguishes the impact of different sources of changes in income distribution in an empirical study of distributional effects on aggregate demand and its components, and it is the first paper to incorporate proxies for the monopoly power of firms into such a study.

Although critics of the structural approach have argued that its typical finding of wage-led, rather than profit-led, demand could be driven by simultaneity bias, the estimates reported here do not support that view. On the contrary, the bias caused by use of a "single equation" approach (separate estimation of individual equations by OLS) seems to lead to underestimation of wage-led demand effects (or overestimation of profit-led outcomes)

\footnotetext{
${ }^{28}$ For example, a one standard deviation shock to monopoly power measured by $\mu A M R$ in Model 2 is estimated to cause the wage share to rise by around 8.5 percentage points in the 1982-2016 period (see Table 1), which is greater than the maximum variation in our wage share series during the entire sample period of about 5.1 percentage points.
} 
compared with systems GMM estimates. In addition, the analysis in this paper also suggests a rethinking of how the relationship between income distribution and aggregate demand should be modeled. Once the wage share is endogenized, instead of calculating the effects of exogenous shocks to the wage share itself, we have to analyze the effects of shocks to the underlying determinants of the wage share such as unit labor costs and firms' monopoly power. This in turn implies that the standard distinction between wage-led and profit-led demand regimes is too simple, as different shocks that can raise the wage share operate may have different effects on total private demand.

Indeed, our results confirm that a redistribution of income toward labor has different effects on demand depending on the source of the distributional shift and the channels through which that source operates. A rise in $U L C$ definitely worsens net exports, and hence can lead to a profit-led response of demand unless the impact on the wage share and domestic demand are sufficiently positive to offset the fall in net exports. Our estimates indicate that the negative effects on net exports dominated in the 1963-1981 period, but not in 1982-2016. Even if the positive domestic effects are large enough to outweigh the negative impact on net exports, as in the latter period, the overall positive impact may be statistically insignificant, that is, the difference between the positive domestic effect and the negative net export effect may not be significantly different from zero. In contrast, a decrease in firms' monopoly power has no negative effect on net exports (in some of our estimates, it has a positive effect), while also increasing the wage share and domestic demand, so it is more likely to be expansionary, i.e., to foster wage-led demand.

Naturally, the present analysis still contains a number of limitations that call for additional research. Especially, the method of adding up the marginal effects on consumption, investment, and net exports to determine the total or net impact of a distributional shift does not capture all of the dynamic interactions of the variables, for example, multiplieraccelerator links between consumption, output, and investment. To address this, it would be necessary to trace out the dynamic effects of a distributional shock on the whole system 
of equations over time through impulse responses of a suitably specified model. Improving on our admittedly imperfect proxies for the monopoly power of firms would also be helpful.

In spite of these limitations, the present findings do have some tentative policy implications. The results suggest that redistributing income toward workers via increased wages relative to productivity (i.e., unit labor costs) - even if effective in increasing the wage share of national income - would shift the composition of aggregate demand, by boosting consumption and residential investment while significantly dampening exports (with smaller or statistically insignificant effects in reducing business investment and/or increasing imports), at least in the short run. In contrast, redistributing income toward labor by reducing the monopoly power of firms would have a more unambiguously positive impact on US private sector demand, because reduced monopoly power would not have the same offsetting impact on net exports as increased labor costs would have. Thus, one tentative conclusion is the importance of efforts to revive anti-trust enforcement, reduce excessive intellectual property protection, and break up large monopolistic or oligopolistic firms, all of which could result in improved macroeconomic performance along with greater distributional equity. 


\section{References}

Autor, D., D. Dorn, L. F. Katz, C. Patterson, and J. V. Reenen (2020). The fall of the labor share and the rise of superstar firms. Quarterly Journal of Economics 135(2), 645-709.

Barbosa-Filho, N. H. and L. Taylor (2006). Distributive and demand cycles in the US economy: A structuralist Goodwin model. Metroeconomica 57(3), 389-411.

Barrales, J. and R. von Arnim (2017). Longer run distributive cycles: Wavelet decompositions for the US, 1948-2011. Review of Keynesian Economics 5(2), 196-217.

Basu, S. (2019). Are price-cost markups rising in the United States? A discussion of the evidence. Journal of Economic Perspectives 33(3), 3-22.

Bhaduri, A. and S. A. Marglin (1990). Unemployment and the real wage: The economic basis for contesting political ideologies. Cambridge Journal of Economics 14(4), 375-393.

Blecker, R. A. (1989). International competition, income distribution and economic growth. Cambridge Journal of Economics 13(3), 395-412.

Blecker, R. A. (1996). The trade deficit and U.S. competitiveness. In R. A. Blecker (Ed.), U.S. Trade Policy and Global Growth: New Directions in the International Economy, pp. 179-214. Armonk, NY: M.E. Sharpe, Economic Policy Institute Series.

Blecker, R. A. (1999). Kaleckian macro models for open economies. In J. Deprez and J. T. Harvey (Eds.), Foundations of International Economics: Post Keynesian Perspectives, pp. 116-149. London and New York: Routledge.

Blecker, R. A. (2002). Demand, distribution, and growth in neo-Kaleckian macro models. In M. Setterfield (Ed.), The Economics of Demand-Led Growth: Challenging the Supply-Side Vision of the Long Run, pp. 129-152. Cheltenham: Edward Elgar.

Blecker, R. A. (2011). Open economy models of growth and distribution. In E. Hein and E. Stockhammer (Eds.), A Modern Guide to Keynesian Macroeconomics and Economic Policies, pp. 215-239. Cheltenham, UK, and Northampton, MA, USA: Edward Elgar.

Blecker, R. A. (2016a). The US economy since the crisis: slow recovery and secular stagnation. European Journal of Economics and Economic Policies: Intervention 13(2), 203-214.

Blecker, R. A. (2016b). Wage-led versus profit-led demand regimes: The long and the short of it. Review of Keynesian Economics 4 (4), 373-390.

Blecker, R. A. and M. Setterfield (2019). Heterodox Macroeconomics: Models of Demand, Distribution and Growth. Cheltenham, UK: Edward Elgar.

Bowles, S. and R. Boyer (1995). Wages, aggregate demand, and employment in an open economy: An empirical investigation. In G. Epstein and H. Gintis (Eds.), Macroeconomic 
Policy After the Conservative Era, pp. 143-171. Cambridge, UK: Cambridge University Press.

Breusch, T. S. and A. R. Pagan (1980). The Lagrange multiplier test and its applications to model specification in econometrics. Review of Economic Studies 47(1), 239-253.

Carvalho, L. and A. Rezai (2016). Personal income inequality and aggregate demand. Cambridge Journal of Economics 40(2), 491-505.

Cauvel, M. (2019). The neo-Goodwinian model reconsidered. PKES Working Paper No. 1915.

Charpe, M., S. Bridji, and P. McAdam (2019). Labor share and growth in the long run. Macroeconomic Dynamics. Published online 27 March.

Cynamon, B. Z. and S. M. Fazzari (2017). Secular demand stagnation in the 21st century U.S. economy. Paper Presented at INET Secular Stagnation Conference, December.

Darvas, Z. (2012). Real effective exchange rates for 178 countries: a new database. Working Paper 2012/06, Bruegel. https://bruegel.org/publications/datasets/real-effectiveexchange-rates-for-178-countries-a-new-database/.

De Loecker, J., J. Eeckhout, and G. Unger (2020). The rise of market power and the macroeconomic implications. Quarterly Journal of Economics 135(2), 561-644.

Elsby, M. W. L., B. Hobijn, and A. Şahin (2013). The decline of the U.S. labor share. Brookings Papers on Economic Activity (Fall), 1-52.

Fernandez, J. V. (2005). Income Distribution and Aggregate Demand in the U.S. Economy: An Empirical Investigation. Unpublished Ph.D. dissertation, American University, Washington, D.C.

Furceri, D. and P. Loungani (2018). The distributional effects of capital account liberalization. Journal of Development Economics 130(January), 127-144.

Gordon, D. M. (1995). Growth, distribution, and the rules of the game: Social structuralist macro foundations for a democratic economic policy. In G. Epstein and H. Gintis (Eds.), Macroeconomic Policy After the Conservative Era, pp. 335-383. Cambridge, UK: Cambridge University Press.

Greene, W. H. (2011). Econometric Analysis (7 ed.). Boston: Pearson.

Hein, E. (2014). Distribution and Growth After Keynes. Cheltenham, UK: Edward Elgar.

Hein, E. and L. Vogel (2008). Distribution and growth reconsidered: Empirical results for six OECD countries. Cambridge Journal of Economics 32(3), 479-511. 
Jayadev, A. (2007). Capital account openness and the labour share of income. Cambridge Journal of Economics 31(3), 423-443.

Karabarbounis, L. and B. Neiman (2014). The global decline of the labor share. Quarterly Journal of Economics 129(1), 61-103.

Karabarbounis, L. and B. Neiman (2018). Accounting for factorless income. NBER Macroeconomics Annual 33, 167-228.

Kiefer, D. and C. Rada (2015). Profit maximising goes global: The race to the bottom. Cambridge Journal of Economics 39(5), 1333-1350.

Kohler, K., A. Guschanski, and E. Stockhammer (2019). The impact of financialisation on the wage share: a theoretical clarification and empirical test. Cambridge Journal of Economics 43(4), 937-974.

Lavoie, M. (2014). Post-Keynesian Economics: New Foundations. Cheltenham, UK; Northampton, MA: Edward Elgar.

Lavoie, M. (2017). The origins and evolution of the debate on wage-led and profit-led regimes. European Journal of Economics and Economic Policies: Intervention 14(2), 200-221.

Marglin, S. A. and A. Bhaduri (1990). Profit squeeze and Keynesian theory. In S. A. Marglin and J. B. Schor (Eds.), The Golden Age of Capitalism, pp. 153-186. Oxford, UK: Oxford University Press.

Naastepad, C. and S. Storm (2006). OECD demand regimes (1960-2000). Journal of Post Keynesian Economics 29(2), 211-246.

Nikiforos, M. and D. K. Foley (2012). Distribution and capacity utilization: Conceptual issues and empirical evidence. Metroeconomica 63(1), 200-229.

Obst, T., Ö. Onaran, and M. Nikolaidi (2017). The effect of income distribution and fiscal policy on growth, investment, and budget balance: the case of Europe. Working Paper GPERC 43, Greenwich Political Economy Research Centre.

Onaran, Ö. and G. Galanis (2012). Is aggregate demand wage-led or profit-led? National and global effects. Working paper, International Labour Organization.

Onaran, Ö. and T. Obst (2016). Wage-led growth in the EU15 member-states: the effects of income distribution on growth, investment, trade balance and inflation. Cambridge Journal of Economics 40(6), 1517-1551.

Onaran, Ö., E. Stockhammer, and L. Grafl (2011). Financialisation, income distribution and aggregate demand in the USA. Cambridge Journal of Economics 35(4), 637-661. 
Pacitti, A. (2015). Bargaining power, labor market institutions, and the Great Moderation. Eastern Economic Journal 41(2), 160-182.

Pariboni, R. and P. Tridico (2019). Labour share decline, financialisation and structural change. Cambridge Journal of Economics 43(4), 1073-1102.

Setterfield, M. and Y. K. Kim (2017). Household borrowing and the possibility of 'consumption-driven, profit-led growth'. Review of Keynesian Economics 5(1), 43-60.

Stockhammer, E. (2017a). Determinants of the wage share: A panel analysis of advanced and developing economies. British Journal of Industrial Relations 55(1), 3-33.

Stockhammer, E. (2017b). Wage-led versus profit-led demand: what have we learned? A Kaleckian-Minskyan view. Review of Keynesian Economics 5(1), 25-42.

Stockhammer, E., E. Hein, and L. Grafl (2011). Globalization and the effects of changes in functional income distribution on aggregate demand in Germany. International Review of Applied Economics 25(1), 1-23.

Stockhammer, E. and J. Michell (2016). Pseudo-Goodwin cycles in a Minsky model. Cambridge Journal of Economics 41(1), 105-125.

Stockhammer, E., Ö. Onaran, and S. Ederer (2009). Functional income distribution and aggregate demand in the euro area. Cambridge Journal of Economics 33(1), 139-159.

Stockhammer, E., J. Rabinovich, and N. Reddy (2018). Distribution, wealth and demand regimes in historical perspective: USA, UK, France and Germany, 1855-2010. Working Paper 1805, Post-Keynesian Economics Society.

Stockhammer, E. and R. Stehrer (2011). Goodwin or Kalecki in demand? Functional income distribution and aggregate demand in the short run. Review of Radical Political Economics 43(4), 506-522.

Stockhammer, E. and R. Wildauer (2016). Debt-driven growth? Wealth, distribution and demand in OECD countries. Cambridge Journal of Economics 40(6), 1609-1634.

Summers, L. H. (2015). Demand side secular stagnation. American Economic Review: Papers and Proceedings 105(5), 60-65.

Taylor, L. (1983). Structuralist Macroeconomics: Applicable Models for the Third World. New York: Basic Books. 


\section{A Appendix: Data set, instruments, and descriptive statistics}

Table A.1: Variable Definitions and Data Sources

\begin{tabular}{|c|c|c|c|}
\hline Variable & Definition & Units & Source \\
\hline GDP, $Y$ & Real gross domestic product & $\begin{array}{l}\text { Billions of } 2009 \\
\text { chained US dollars }\end{array}$ & BEA \\
\hline Consumption, $C$ & $\begin{array}{l}\text { Real personal consumption } \\
\text { expenditures }\end{array}$ & $\begin{array}{l}\text { Billions of } 2009 \\
\text { chained US dollars }\end{array}$ & BEA \\
\hline $\begin{array}{l}\text { Residential } \\
\text { investment, } I_{\text {res }}\end{array}$ & $\begin{array}{l}\text { Private, fixed residential } \\
\text { investment deflated by price } \\
\text { index for private, fixed } \\
\text { residential investment }\end{array}$ & $\begin{array}{l}\text { Billions of } 2009 \text { US } \\
\text { dollars }\end{array}$ & $\begin{array}{l}\text { BEA; authors' } \\
\text { calculations }\end{array}$ \\
\hline $\begin{array}{l}\text { Nonresidential } \\
\text { investment, } I_{n r}\end{array}$ & $\begin{array}{l}\text { Private, fixed nonresidential } \\
\text { investment deflated by price } \\
\text { index for private, fixed } \\
\text { nonresidential investment }\end{array}$ & $\begin{array}{l}\text { Billions of } 2009 \text { US } \\
\text { dollars }\end{array}$ & $\begin{array}{l}\text { BEA; authors' } \\
\text { calculations }\end{array}$ \\
\hline Exports, $X$ & $\begin{array}{l}\text { Real exports of goods and } \\
\text { services }\end{array}$ & $\begin{array}{l}\text { Billions of } 2009 \\
\text { chained US dollars }\end{array}$ & BEA \\
\hline Imports, $M$ & $\begin{array}{l}\text { Real imports of goods and } \\
\text { services }\end{array}$ & $\begin{array}{l}\text { Billions of } 2009 \\
\text { chained US dollars }\end{array}$ & BEA \\
\hline Foreign income, $Y_{f}$ & $\begin{array}{l}\text { Total OECD GDP - US GDP } \\
\text { (volume estimates, fixed PPPs), } \\
\text { average of quarterly series }\end{array}$ & $\begin{array}{l}\text { Millions of } 2010 \text { US } \\
\text { dollars }\end{array}$ & $\begin{array}{l}\text { OECD; authors' } \\
\text { calculations }\end{array}$ \\
\hline Wages, $W$ & $\begin{array}{l}\text { Total labor compensation } \\
\text { (wages and salaries plus } \\
\text { supplements) deflated by GDP } \\
\text { price index }\end{array}$ & $\begin{array}{l}\text { Billions of } 2009 \text { US } \\
\text { dollars }\end{array}$ & $\begin{array}{l}\text { BEA; authors' } \\
\text { calculations }\end{array}$ \\
\hline Profits, $R$ & $\begin{array}{l}\text { Gross operating surplus = net } \\
\text { operating surplus + private } \\
\text { consumption of fixed capital, } \\
\text { deflated by GDP price index }\end{array}$ & $\begin{array}{l}\text { Billions of } 2009 \text { US } \\
\text { dollars }\end{array}$ & $\begin{array}{l}\text { BEA; authors' } \\
\text { calculations }\end{array}$ \\
\hline $\begin{array}{l}\text { Wage share, total } \\
\text { economy, } \psi\end{array}$ & $\begin{array}{l}\text { Total labor compensation as } \\
\text { percentage of nominal GDP }\end{array}$ & Percentage & $\begin{array}{l}\text { BEA; authors' } \\
\text { calculations }\end{array}$ \\
\hline $\begin{array}{l}\text { Wage share, } \\
\text { nonfarm business } \\
\text { and nonfinancial } \\
\text { corporations }\end{array}$ & Indexes & $\begin{array}{l}\text { Indexes, } 2012= \\
100\end{array}$ & BLS \\
\hline Corporate debt & $\begin{array}{l}\text { Total liabilities and equity of } \\
\text { nonfinancial corporate business } \\
\text { as a percentage of nominal GDP }\end{array}$ & Percentage & $\begin{array}{l}\text { Fed; BEA; } \\
\text { authors' } \\
\text { calculations }\end{array}$ \\
\hline Household debt & $\begin{array}{l}\text { Total liabilities of households } \\
\text { and nonprofit organizations as a } \\
\text { percentage of nominal GDP }\end{array}$ & Percentage & $\begin{array}{l}\text { Fed; BEA; } \\
\text { authors' } \\
\text { calculations }\end{array}$ \\
\hline $\begin{array}{l}\text { Household net } \\
\text { worth }\end{array}$ & $\begin{array}{l}\text { Net worth of households and } \\
\text { nonprofit organizations as } \\
\text { percentage of nominal GDP }\end{array}$ & Percentage & $\begin{array}{l}\text { Fed; BEA; } \\
\text { authors' } \\
\text { calculations }\end{array}$ \\
\hline
\end{tabular}


Table A.1 - continued from previous page

\begin{tabular}{|c|c|c|c|}
\hline Variable & Definition & Units & Source \\
\hline House prices & $\begin{array}{l}\text { Residential property price index } \\
\text { for new one-family houses, } \\
\text { average of quarterly series, } \\
\text { deflated by GDP price index }\end{array}$ & Index, $2005=100$ & $\begin{array}{l}\text { BEA; BIS; } \\
\text { authors' } \\
\text { calculations }\end{array}$ \\
\hline Real interest rate & $\begin{array}{l}\text { 10-year constant maturity rate } \\
\text { - ten-year average percentage } \\
\text { change in CPI }\end{array}$ & Percentage & $\begin{array}{l}\text { Fed; BLS; } \\
\text { authors' } \\
\text { calculations }\end{array}$ \\
\hline $\begin{array}{l}\text { Gross profit } \\
\text { margin }(\mathrm{GPM})\end{array}$ & $\begin{array}{l}\text { Ratio of (unit net profits }+ \text { unit } \\
\text { capital consumption)/unit labor } \\
\text { costs, nonfinancial corporations }\end{array}$ & Ratio & $\begin{array}{l}\text { BEA; authors' } \\
\text { calculations }\end{array}$ \\
\hline $\begin{array}{l}\text { Average markup } \\
\text { rate (AMR) }\end{array}$ & $\begin{array}{l}\text { Average markup rate, weighted } \\
\text { by market share of sales }\end{array}$ & Ratio & $\begin{array}{l}\text { De Loecker } \\
\text { et al. }(2020)^{\mathrm{a}}\end{array}$ \\
\hline SGA/Sales ratio & $\begin{array}{l}\text { Sales-weighted average ratio of } \\
\text { selling, general and administra- } \\
\text { tive expense to net sales }\end{array}$ & Ratio & $\begin{array}{l}\text { Compustat/ } \\
\text { WRDS; auth- } \\
\text { ors' calculations }\end{array}$ \\
\hline Union activity & $\begin{array}{l}\text { Number of strikes idling } 1,000 \\
\text { or more workers beginning in } \\
\text { the current period }\end{array}$ & Number of strikes & BLS \\
\hline $\begin{array}{l}\text { Manufacturing } \\
\text { share of } \\
\text { employment }\end{array}$ & $\begin{array}{l}\text { All manufacturing employees as } \\
\text { a percentage of all employees in } \\
\text { total private industries }\end{array}$ & Percentage & $\begin{array}{l}\text { BLS; authors' } \\
\text { calculations }\end{array}$ \\
\hline $\begin{array}{l}\text { Inflation } \\
\text { expectations }\end{array}$ & $\begin{array}{l}\text { Livingston Survey, one-year } \\
\text { ahead forecast of CPI-U infla- } \\
\text { tion rate, end of previous year }\end{array}$ & Percentage & $\begin{array}{l}\text { Federal Reserve } \\
\text { Bank of } \\
\text { Philadelphia } \\
\end{array}$ \\
\hline $\begin{array}{l}\text { Unit labor costs, } \\
\text { nominal, total } \\
\text { economy, } U L C\end{array}$ & $\begin{array}{l}\text { Wage share } \times \text { domestic price } \\
\text { level }\end{array}$ & $\begin{array}{l}\text { Index, normalized } \\
\text { to sample mean }= \\
1\end{array}$ & $\begin{array}{l}\text { BEA; authors' } \\
\text { calculations }\end{array}$ \\
\hline $\begin{array}{l}\text { Unit labor costs, } \\
\text { nominal, nonfarm } \\
\text { business and } \\
\text { nonfinancial } \\
\text { corporations }\end{array}$ & Indexes & $\begin{array}{l}\text { Indexes, } 2012= \\
100\end{array}$ & BLS \\
\hline $\begin{array}{l}\text { Price of foreign } \\
\text { goods in US } \\
\text { dollars, } E P_{f}\end{array}$ & $\begin{array}{l}\text { CPI for all urban consumers } \\
\text { divided by annual real effective } \\
\text { exchange rate index for US } \\
\text { dollar with } 67 \text { countries }\end{array}$ & $\begin{array}{l}\text { Index, rebased to } \\
2012=100\end{array}$ & $\begin{array}{l}\text { BLS; Darvas } \\
(2012)^{\mathrm{c}} ; \\
\text { authors' } \\
\text { calculations }\end{array}$ \\
\hline $\begin{array}{l}\text { Labor cost } \\
\text { competitiveness } \\
\text { ratio, } z\end{array}$ & $\begin{array}{l}\text { Ratio of prices of foreign goods } \\
\text { in US dollars to nominal unit } \\
\text { labor costs, } z=E P_{f} / U L C\end{array}$ & $\begin{array}{l}\text { Index, normalized } \\
\text { to sample mean }= \\
1\end{array}$ & $\begin{array}{l}\text { Authors' } \\
\text { calculations }\end{array}$ \\
\hline
\end{tabular}

Notes: Some series were downloaded via the FRED database of the Federal Reserve Bank of St. Louis.

a Downloaded from https://sites.google.com/site/deloeckerjan/data-and-code, accessed 20 May 2019.

b Unit nonlabor costs are the sum of consumption of fixed capital, taxes on production and imports, net interest, and miscellaneous items. Unit labor costs are equivalent to compensation of employees. All variables are measured in nominal dollars per unit of real gross value added of nonfinancial domestic corporate business.

${ }^{\mathrm{c}}$ Downloaded from https://bruegel.org/publications/datasets/real-effective-exchange-rates-for-178-countriesa-new-database/, last updated 28 June 2018, accessed 9 June 2019. 
Table A.2: Number of lags used as instruments for each variable and tests of overidentifying restrictions in models estimated by GMM

\begin{tabular}{|c|c|c|}
\hline Variable & Model 1 & Model 2 \\
\hline$\Delta \ln I_{r e s}$ & 1 & 1 \\
\hline$\Delta \ln I_{n r}$ & $1-2$ & $1-2$ \\
\hline$\Delta \ln X$ & 1 & 1 \\
\hline$\Delta \ln M$ & 1 & 1 \\
\hline$\Delta \ln W$ & $1-4$ & $1-4$ \\
\hline$\Delta \ln R$ & $1-4$ & $1-4$ \\
\hline$\Delta \ln Y$ & $1-4$ & $1-4$ \\
\hline$\Delta \ln Y_{f}$ & $0-1$ & $0-1$ \\
\hline$\Delta \ln \psi$ & $1-4$ & $1-4$ \\
\hline$\Delta \ln U L C$ & $1-4$ & $1-4$ \\
\hline$\Delta \ln E P_{f}$ & $0-1$ & $0-1$ \\
\hline$\Delta \ln$ Household net worth & $1-3$ & $1-3$ \\
\hline$\Delta \ln$ Corporate debt & $1-4$ & $1-3$ \\
\hline$\Delta \ln$ Manufacturing share & $1-4$ & $1-3$ \\
\hline$\Delta \ln$ Union activity & $1-4$ & $1-3$ \\
\hline Inflation expectations & 0 & 0 \\
\hline$\Delta \ln \mu_{G P M}$ & $1-4$ & \\
\hline$\Delta \ln \mu_{A M R}$ & & $1-4$ \\
\hline$\Delta \ln \mathrm{SGA} /$ Sales ratio & & $1-3$ \\
\hline 1981-2016 Dummy & 0 & 0 \\
\hline 1982-2016 Dummy & 0 & 0 \\
\hline 1976 Dummy & 0 & 0 \\
\hline 1989 Dummy & 0 & \\
\hline Number of observations & 54 & 54 \\
\hline Number of parameters to estimate & 43 & 45 \\
\hline Number of moments & 378 & 371 \\
\hline Hansen $J$-statistic & 367.348 & 349.645 \\
\hline Chi-square degrees of freedom & 335 & 326 \\
\hline$p$-value & 0.1080 & 0.1761 \\
\hline
\end{tabular}

Notes: A constant was also included as an instrument in each model. No lags of $C$ were used as instruments because none are included in the consumption function. Inflation expectations are considered lagged because they are from the end of the previous year. See section 4 for discussion of criteria for selecting instruments. 
Table A.3: Sample means of ratios and standard deviations of shocks used to calculate marginal effects

\begin{tabular}{lccc}
\hline Period & $1963-2016$ & $1963-1981$ & $1982-2016$ \\
\hline Mean of ratio & & & \\
\hline$C / Y$ & 0.640 & 0.613 & 0.655 \\
$C / W$ & 1.156 & 1.091 & 1.192 \\
$C / R$ & 1.888 & 1.917 & 1.873 \\
$I_{\text {res }} / W$ & 0.094 & 0.112 & 0.084 \\
$I_{n r} / W$ & 0.198 & 0.168 & 0.214 \\
$\psi / \mu_{G P M}$ (Model 1) & 1.416 & & \\
$\psi / \mu_{A M R}$ (Model 2) & 0.406 & & \\
$(X / Y) / \mu_{G P M}$ (Model 1) & 0.184 & & \\
$(X / Y) / \mu_{A M R}$ (Model 2) & 0.053 & & \\
$(M / Y) / \mu_{G P M}$ (Model 1) & 0.234 & & \\
$(M / Y) / \mu_{A M R}$ (Model 2) & 0.068 & & \\
$\psi / U L C$ & & 1.354 & 0.446 \\
$(X / Y) / U L C$ & & 0.098 & 0.070 \\
$(M / Y) / U L C$ & & 0.122 & 0.089 \\
\hline Standard deviation of shock & & \\
\hline$\mu_{G P M}$ (Model 1) & 0.057 & & \\
$\mu_{A M R}$ (Model 2) & 0.090 & & \\
$U L C$ & & 0.150 & 0.263 \\
\hline
\end{tabular}

Note: Data for 1963-2016 are used for estimating marginal effects of shocks to either measure of $\mu$. Data for 1963-1981 and 1982-2016 are used for estimating marginal effects of shocks to $U L C$. 


\section{B Appendix: Estimation results for individual equa- tions}

The tables in this appendix present the econometric estimates of the two models, where Model 1 uses $\mu_{G P M}$ as the proxy for monopoly power of firms and Model 2 uses $\mu_{A M R}$ from De Loecker et al. (2020). There are two sets of GMM estimates for all equations, because Model 1 and Model 2 use different sets of instruments. For a few equations, the OLS specifications also differ between the two models. Hypothesis tests for the individual estimated coefficients are based on $t$ - and z-statistics for the OLS and GMM estimates, respectively; the hypothesis tests for the long-run coefficients are conducted using chi-square tests with one degree of freedom. ${ }^{29}$

The consumption function estimates are given in Table B.1. As expected, the elasticity of consumption with respect to wage income (total labor compensation) is much higher than for profits (total capital income). The marginal propensities to consume are 0.59-0.65 out of wage (labor) income and $0.27-0.34$ out of profit (capital) income, with larger gaps between them in the GMM estimates. These consumption functions do not include any control variables or lags. Initially, we included measures of household debt and net worth, along with the lagged dependent variable. However, net worth and the lagged dependent variable were insignificant and therefore omitted. Household debt was dropped to reduce the number of parameters and help satisfy the overidentifying restriction in GMM. Nevertheless, we were able to obtain statistically valid estimates with this parsimonious specification, as the OLS equation satisfies all the diagnostic tests without any control variables or lags included. The estimated coefficients on wage and profit income (referring to the sums of all lags when lags were included) were robust regardless of whether controls or lags were included or not.

\footnotetext{
${ }^{29}$ Long-run coefficients were calculated as the sum of contemporaneous and lagged coefficients for each independent variable divided by one minus the sum of the coefficients on lags of the dependent variable.
} 
The estimated residential investment functions are shown in Table B.2, where household net worth is used as a control variable. ${ }^{30}$ Because contemporaneous net worth could be endogenous, it is instrumented with its lags in the GMM estimation. GDP growth has a strongly positive and significant contemporaneous effect in all estimates, but a negative lagged effect, resulting in long-run coefficients (elasticities) that are positive but insignificant. The wage share, in contrast, has an insignificant contemporaneous effect, a positive and significant lagged effect, and a large, positive long-run effect that is statistically significant (at the $5 \%$ or $10 \%$ level) in the GMM estimates. Household net worth has a positive and significant effect, as expected.

The nonresidential investment function results shown in Table B.3 include two control variables. The manufacturing share of employment is included on the assumption that manufacturing production is more capital-intensive than most of the rest of the economy. The ratio of corporate debt to GDP is included to account for the role of external finance. Since the debt variable is measured in log differences, it reflects the flow of new corporate borrowing, and is expected to have a positive sign. ${ }^{31}$ For this equation, we found it necessary to include a second lag of the dependent variable to satisfy the Ramsey RESET test. ${ }^{32}$ Although both lags (0 and 1$)$ of the wage share have the expected negative signs, the coefficients are mostly insignificant in the three estimated equations, and the long-run effect of the wage share is negative but insignificant in all three estimates. In contrast, the accelerator

\footnotetext{
${ }^{30}$ Including household net worth also helped eliminate heteroscedasticity in the residuals. House prices were also found to be significant, but including them would have required us to shorten the sample period. Net worth was used instead of household debt because including debt required two lags to yield good econometric properties, thereby increasing the number of parameters in the system.

${ }^{31}$ Because current borrowing is likely to be endogenous, it was instrumented with its lags in the GMM estimates (similar to household net worth in the residential investment function). We also tested a real interest rate variable, but it always had a small and statistically insignificant coefficient so it was omitted.

${ }^{32}$ Including the second lag of the dependent variable resulted in the Schwarz criterion excluding the lagged wage share. Because of the strong theoretical reasons to expect a negative effect of the wage share and in order not to bias our findings in favor of wage-led demand, we included the lagged wage share anyway. It seems plausible that the negative effect of the wage share would be stronger with a lag, if the wage share largely affects planned investment in advance of actual expenditures.
} 
effects are all positive and significant, with long-run GDP elasticities on the order of 1.80 to 1.85, and the two control variables have significant positive effects as expected.

Tables B.4 and B.5 report the estimates of the export and import demand functions, respectively. As in the consumption function, no control variables were needed to obtain statistically valid estimates. According to equations (16) and (17), the monopoly power of domestic firms $(\mu)$ should have a negative effect on exports and a positive effect on imports. However, only the GPM proxy was statistically significant and only in the export equation. To conserve degrees of freedom, the insignificant $\mu_{A M R}$ was omitted from both equations and $\mu_{G P M}$ was omitted from the import equation

In the export equation (Table B.4), $\mu_{G P M}$ has the expected negative coefficient, which is significant at least at the $10 \%$ level, in Model 1. Foreign income has the expected positive effect, with a long-run elasticity of about 1.6-1.7. The $z$ ratio, which reflects US labor cost competitiveness, has the expected positive effect in all of the estimates, with a long-run elasticity ranging from about 0.7 to 1 that is significant at the $1 \%$ level in all four equations. ${ }^{33}$ In addition, foreign income has a strongly positive and significant effect on US exports, with estimated long-run elasticities in the range of about 1.6 to 1.7.

In the import demand function (Table B.4), the domestic income effect is large and significant $\left(1 \%\right.$ level) with a long-run elasticity of about 2.5. ${ }^{34}$ However, the $z$-elasticity of import demand is small in all estimates, and is weakly significant (10\% level) in only two out of three equations. Thus, the short-run impact of US labor cost competitiveness is found to be stronger on exports than on imports, but still positive for net exports overall. ${ }^{35}$

\footnotetext{
${ }^{33}$ Although the lag of $z$ is not statistically significant, its inclusion was found to be necessary to eliminate serial correlation in the residuals.

${ }^{34}$ The fact that the estimated income elasticity is greater for imports than for exports is consistent with many earlier studies (see, for example, Blecker, 1996).

${ }^{35}$ It is possible that persistently high US labor costs could drive industries offshore, leading to long-term increases in imports, but such long-run effects would not be captured in these short-run estimates.
} 
The estimated $U L C$ equations are given in Table B.6. The negative contemporaneous effect of GDP growth on changes in unit labor costs could reflect the positive effect of higher output on labor productivity discussed earlier. The positive lagged effect of GDP growth probably reflects a delayed impact of the resulting higher employment on wage setting. The positive lagged effect more than offsets the negative contemporaneous effect, resulting in positive and significant long-run coefficients for $\Delta \ln G D P$. The two control variables, inflation expectations and union strike activity, have the expected positive signs and are significant at least at the $1 \%$ level. The equation also includes a structural break (intercept shift) in 1981, which as discussed in section 3 likely reflects the adoption of neo-liberal policies and the weakening of labor's bargaining power starting in the early 1980s (the intercept was insignificant when included, and hence was omitted to conserve degrees of freedom).

The estimated wage share equations (18) are given in Table B.7. Because using the labor cost competitiveness ratio $z$ resulted in a very poor fit for this equation, we replaced it with its numerator and denominator, $E P_{f}$ and $U L C$, treated as separate variables-or rather, in $\log$ differences, we used $\Delta \ln \left(E P_{f}\right)$ and $\Delta \ln U L C$ in place of $\Delta \ln z$. In addition, we found it necessary to include a structural break on both the intercept ${ }^{36}$ and the slopes of the $\Delta \ln U L C$ coefficients in order for the equations to pass various diagnostic tests. QuandtAndrews tests indicated that 1982 was the optimal year for this break in Model 1, and for consistency we also used 1982 for the break in Model 2 (which is significant at the 5\% level according to a Chow test). Outlier dummies for large residuals also had to be included to satisfy various diagnostic tests - for 1976 in both models, and also for 1989 in Model 1.

The results for the wage share equations are complicated because of the structural break, and require some explanation. We will focus on the long-run coefficients, shown in the continuation of Table B.7, for the sake of brevity. Surprisingly, the long-run effect of

\footnotetext{
${ }^{36} \mathrm{As}$ in the $U L C$ equation, the intercept itself was insignificant and was omitted to increase degrees of freedom for the GMM estimation; all other results were very similar when the intercept was included.
} 
$\Delta \ln U L C$ is both negative and statistically insignificant. However, given the presence of the interactive slope dummies, that insignificant effect pertains only to the years before 1982 . The long-run slope dummy (dummy for 1982-2016 interacted with $\Delta \ln U L C$ ) is positive and significant, indicating a significant increase in the $U L C$ effect in that period. The total effects of $U L C$ in the 1982-2016 period are the sums of the long-run coefficients on $\Delta \ln U L C$ with and without the interactive dummy, and as indicated in the table they are positive and significant at the $1 \%$ level according to chi-square tests (with elasticities of about 0.3 in Model 1 and 0.7 in Model 2).

What could account for the discrepancy in $U L C$ effects between the two subperiods? While any explanation we can give is purely speculative, one plausible reason is that increases in nominal unit labor costs were more easily and fully passed through into price increases prior to the early 1980s, while globalization effects (greater competition from imports and intensified offshoring of inputs) made such full pass-through into prices more difficult after that time. In contrast, the rate of change in foreign prices converted to US dollars $\left(\Delta \ln \left(E P_{f}\right)\right)$ has the expected negative effect, which is significant in all four equations, with no structural break. Our proxies for the monopoly power of firms, $\mu_{G P M}$ and $\mu_{A M R}$, both have the expected negative coefficients which are statistically significant. For Model 2, which uses $\mu_{A M R}$, we found it necessary to include an additional control variable. One of the criticisms of the AMR measure from De Loecker et al. (2020) is that it does not adequately correct for the rising share of overhead costs in firms' total costs. We therefore used the SGA/Sales ratio as a control variable. The SGA/Sales ratio has a significant positive effect, most likely because it reflects the rising proportion of non-production workers in the labor force (which helps to keep the wage share higher than it would be otherwise). 
Table B.1: Estimated consumption functions Dependent Variable: $\Delta \ln C_{t}$ Sample period: 1963-2016 (54 observations)

\begin{tabular}{lccc}
\hline Estimation method & OLS & \multicolumn{2}{c}{ GMM } \\
& & Model 1 & Model 2 \\
\hline Constant & $0.012^{* * *}$ & $0.011^{* * *}$ & $0.012^{* * *}$ \\
& $(0.002)$ & $(0.002)$ & $(0.002)$ \\
$\Delta \ln W_{t}$ & $0.514^{* * *}$ & $0.543^{* * *}$ & $0.564^{* * *}$ \\
& $(0.060)$ & $(0.056)$ & $(0.054)$ \\
$\Delta \ln R_{t}$ & $0.179^{* * *}$ & $0.165^{* * *}$ & $0.141^{* * *}$ \\
& $(0.043)$ & $(0.040)$ & $(0.038)$ \\
\hline Marginal propensities to consume: & & & \\
\hline$c_{W}$ & 0.59 & 0.63 & 0.65 \\
$c_{R}$ & 0.34 & 0.31 & 0.27 \\
\hline$R^{2}$ & 0.769 & & \\
Adjusted $R^{2}$ & 0.760 & & \\
Schwarz Criterion & -6.494 & & \\
$p$-values for $F$-statistics: & & & \\
Jarque-Bera & 0.798 & & \\
Breusch-Godfrey & 0.425 & & \\
Breusch-Pagan-Godfrey & 0.109 & & \\
RESET (1) & 0.574 & & \\
RESET (2) & 0.821 & & \\
\hline
\end{tabular}

Notes: Numbers in parentheses are standard errors. Significance levels $(* * * 1 \%, * * 5 \%, *$ $10 \%)$ are based on $t$-tests for OLS and $z$-tests for GMM. Instruments used in the GMM estimation and Hansen $J$-statistics for each model (1 and 2) are presented in Table A.2. 
Table B.2: Estimated residential investment functions

Dependent Variable: $\Delta \ln I_{\text {res }, t}$

Sample period: 1963-2016 (54 observations)

\begin{tabular}{|c|c|c|c|}
\hline \multirow[t]{2}{*}{ Estimation method } & \multirow[t]{2}{*}{ OLS } & \multicolumn{2}{|c|}{ GMM } \\
\hline & & Model 1 & Model 2 \\
\hline \multirow[t]{2}{*}{$\Delta \ln I_{r e s, t-1}$} & $0.457 * * *$ & $0.496^{* * *}$ & $0.525 * * *$ \\
\hline & $(0.096)$ & $(0.076)$ & $(0.075)$ \\
\hline \multirow[t]{2}{*}{$\Delta \ln Y_{t}$} & $3.957^{* * *}$ & $4.000 * * *$ & $3.920 * * *$ \\
\hline & $(0.516)$ & $(0.453)$ & $(0.451)$ \\
\hline \multirow[t]{2}{*}{$\Delta \ln Y_{t-1}$} & $-3.597^{* * *}$ & $-3.695^{* * *}$ & $-3.609^{* * *}$ \\
\hline & $(0.529)$ & $(0.459)$ & $(0.457)$ \\
\hline \multirow[t]{2}{*}{$\Delta \ln \psi_{t}$} & -0.113 & 0.608 & -0.228 \\
\hline & $(1.182)$ & $(1.004)$ & $(1.021)$ \\
\hline \multirow[t]{2}{*}{$\Delta \ln \psi_{t-1}$} & $2.326^{* *}$ & $2.205^{* *}$ & $2.607 * * *$ \\
\hline & $(1.048)$ & $(0.874)$ & $(0.877)$ \\
\hline \multirow[t]{2}{*}{$\Delta \ln$ Household net worth $_{t}$} & $0.564^{* *}$ & $0.438 * *$ & $0.418^{* *}$ \\
\hline & $(0.239)$ & $(0.190)$ & $(0.190)$ \\
\hline \multicolumn{4}{|l|}{ Long-run coefficients: } \\
\hline \multirow[t]{2}{*}{$\overline{\Delta \ln Y}$} & 0.663 & 0.605 & 0.654 \\
\hline & {$[1.37]$} & {$[1.14]$} & {$[1.20]$} \\
\hline \multirow[t]{2}{*}{$\Delta \ln \psi$} & 4.075 & $5.579 * *$ & $5.005^{*}$ \\
\hline & {$[1.98]$} & {$[4.17]$} & {$[3.05]$} \\
\hline \multirow[t]{2}{*}{$\Delta \ln$ Household net worth $_{t}$} & $1.038^{* *}$ & $0.869^{* *}$ & $0.879^{* *}$ \\
\hline & {$[5.10]$} & {$[5.16]$} & {$[4.73]$} \\
\hline$R^{2}$ & 0.688 & & \\
\hline Adjusted $R^{2}$ & 0.656 & & \\
\hline Schwarz Criterion & -2.059 & & \\
\hline \multicolumn{4}{|l|}{$p$-values for $F$-statistics: } \\
\hline Jarque-Bera & 0.524 & & \\
\hline Breusch-Godfrey & 0.310 & & \\
\hline Breusch-Pagan-Godfrey & 0.114 & & \\
\hline RESET (1) & 0.892 & & \\
\hline RESET (2) & 0.963 & & \\
\hline
\end{tabular}

Notes: Numbers in parentheses are standard errors; numbers in square brackets are chisquare statistics for the null hypothesis (restriction) that the long-run effect is zero. Significance levels $(* * * 1 \%, * * 5 \%, * 10 \%)$ are based on $t$-statistics (OLS) and $z$-statistics (GMM) for short-run coefficients, and $\chi^{2}(1)$ for long-run coefficients. Instruments used in the GMM estimation and Hansen $J$-statistics for each model (1 and 2) are presented in Table A.2. 
Table B.3: Estimated nonresidential investment functions

Dependent Variable: $\Delta \ln I_{n r, t}$ Sample period: 1963-2016 (54 observations)

\begin{tabular}{|c|c|c|c|}
\hline \multirow[t]{2}{*}{ Estimation method } & \multirow[t]{2}{*}{ OLS } & \multicolumn{2}{|c|}{ GMM } \\
\hline & & Model 1 & Model 2 \\
\hline$\Delta \ln I_{n r, t-1}$ & $\begin{array}{c}0.391^{* * *} \\
(0.078)\end{array}$ & $\begin{array}{c}0.391^{* * *} \\
(0.062)\end{array}$ & $\begin{array}{c}0.395^{* * *} \\
(0.063)\end{array}$ \\
\hline$\Delta \ln I_{n r, t-2}$ & $\begin{array}{c}-0.174^{* *} \\
(0.076)\end{array}$ & $\begin{array}{c}-0.224^{* * *} \\
(0.058)\end{array}$ & $\begin{array}{c}-0.227^{* * *} \\
(0.059)\end{array}$ \\
\hline$\Delta \ln Y_{t}$ & $\begin{array}{c}1.452^{* * *} \\
(0.163)\end{array}$ & $\begin{array}{c}1.522^{\text {*** }} \\
(0.135)\end{array}$ & $\begin{array}{c}1.498^{* * *} \\
(0.137)\end{array}$ \\
\hline$\Delta \ln \psi_{t}$ & $\begin{array}{l}-0.087 \\
(0.443)\end{array}$ & $\begin{array}{l}-0.248 \\
(0.375)\end{array}$ & $\begin{array}{l}-0.189 \\
(0.392)\end{array}$ \\
\hline$\Delta \ln \psi_{t-1}$ & $\begin{array}{c}-0.732^{*} \\
(0.411)\end{array}$ & $\begin{array}{l}-0.326 \\
(0.346)\end{array}$ & $\begin{array}{l}-0.413 \\
(0.351)\end{array}$ \\
\hline$\Delta \ln$ Manufacturing share $t$ & $\begin{array}{c}0.710^{* * *} \\
(0.182)\end{array}$ & $\begin{array}{c}0.688^{* * *} \\
(0.144)\end{array}$ & $\begin{array}{c}0.666^{* * *} \\
(0.146)\end{array}$ \\
\hline$\Delta \ln$ Corporate debt $t$ & $\begin{array}{c}0.017 \\
(0.039)\end{array}$ & $\begin{array}{c}0.036 \\
(0.032)\end{array}$ & $\begin{array}{c}0.029 \\
(0.032)\end{array}$ \\
\hline 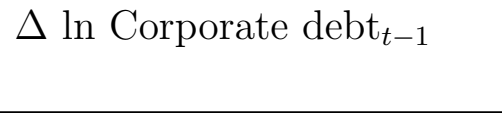 & $\begin{array}{c}0.103^{* *} \\
(0.049)\end{array}$ & $\begin{array}{c}0.086^{* *} \\
(0.038)\end{array}$ & $\begin{array}{c}0.088^{* *} \\
(0.039)\end{array}$ \\
\hline Long-run coefficients: & & & \\
\hline$\Delta \ln Y$ & $\begin{array}{c}1.853^{* * *} \\
{[78.13]}\end{array}$ & $\begin{array}{c}1.825^{* * *} \\
{[128.84]}\end{array}$ & $\begin{array}{c}1.799^{* * *} \\
{[122.56]}\end{array}$ \\
\hline$\Delta \ln \psi$ & $\begin{array}{c}-1.045 \\
{[1.51]}\end{array}$ & $\begin{array}{c}-0.689 \\
{[1.14]}\end{array}$ & $\begin{array}{c}-0.723 \\
{[1.18]}\end{array}$ \\
\hline$\Delta \ln$ Manufacturing share & $\begin{array}{c}0.906^{* * *} \\
{[10.05]}\end{array}$ & $\begin{array}{c}0.825^{* * *} \\
{[16.42]}\end{array}$ & $\begin{array}{c}0.800 * * * \\
{[15.01]}\end{array}$ \\
\hline$\Delta \ln$ Corporate debt & $\begin{array}{c}0.153^{*} \\
{[3.07]} \\
\end{array}$ & $\begin{array}{c}0.147^{* *} \\
{[5.28]}\end{array}$ & $\begin{array}{c}0.141^{* *} \\
{[4.70]}\end{array}$ \\
\hline$R^{2}$ & 0.829 & & \\
\hline Adjusted $R^{2}$ & 0.803 & & \\
\hline $\begin{array}{l}\text { Schwarz Criterion } \\
p \text {-values for } F \text {-statistics: }\end{array}$ & -4.023 & & \\
\hline$\overline{\text { Jarque-Bera }}$ & 0.494 & & \\
\hline Breusch-Godfrey & 0.929 & & \\
\hline Breusch-Pagan-Godfrey & 0.839 & & \\
\hline RESET (1) & 0.130 & & \\
\hline RESET (2) & 0.286 & & \\
\hline
\end{tabular}

Notes: Same as for Table B.2. 
Table B.4: Estimated export demand functions

Dependent Variable: $\Delta \ln X_{t}$

Sample period: 1963-2016 (54 observations)

\begin{tabular}{lcccc}
\hline \multirow{2}{*}{ Estimation method } & OLS & GMM & OLS & GMM \\
\hline$\Delta \ln X_{t-1}$ & $0.456^{* * *}$ & $0.373^{* * *}$ & $0.456^{* * *}$ & $0.378^{* * *}$ \\
& $(0.118)$ & $(0.098)$ & $(0.121)$ & $(0.099)$ \\
$\Delta \ln Y_{f, t}$ & $2.516^{* * *}$ & $2.315^{* * *}$ & $2.374^{* * *}$ & $2.235^{* * *}$ \\
$\Delta \ln Y_{f, t-1}$ & $(0.252)$ & $(0.219)$ & $(0.250)$ & $(0.216)$ \\
& $-1.663^{* * *}$ & $-1.291^{* * *}$ & $-1.474^{* * *}$ & $-1.186^{* * *}$ \\
$\Delta \ln z_{t}$ & $(0.360)$ & $(0.302)$ & $(0.359)$ & $(0.297)$ \\
& $0.409^{* * *}$ & $0.387^{* * *}$ & $0.385^{* * *}$ & $0.370^{* * *}$ \\
$\Delta \ln z_{t-1}$ & $(0.086)$ & $(0.074)$ & $(0.088)$ & $(0.076)$ \\
& 0.146 & 0.126 & 0.121 & 0.086 \\
$\Delta \ln \mu_{G P M, t}$ & $(0.103)$ & $(0.086)$ & $(0.106)$ & $(0.087)$ \\
& $-0.148^{* *}$ & $-0.111^{*}$ & & \\
\hline Long-run coefficients: & $(0.072)$ & $(0.064)$ & & \\
\hline$\Delta \ln Y_{f}$ & & & & \\
& $1.569^{* * *}$ & $1.632^{* * *}$ & $1.654^{* * *}$ & $1.686^{* * *}$ \\
$\Delta \ln z$ & {$[55.35]$} & {$[92.78]$} & {$[59.85]$} & {$[93.24]$} \\
& $1.021^{* * *}$ & $0.818^{* * *}$ & $0.929^{* * *}$ & $0.733^{* * *}$ \\
$\Delta \ln \mu_{G P M}$ & {$[20.47]$} & {$[30.98]$} & {$[18.70]$} & {$[26.45]$} \\
& $-0.272^{*}$ & $-0.176^{*}$ & & \\
\hline$R^{2}$ & {$[3.51]$} & {$[2.82]$} & & \\
Adjusted $R^{2}$ & 0.749 & & 0.727 & \\
Schwarz Criterion & 0.723 & & 0.705 & \\
$p$-values for $F$-statistics: & -4.032 & & -4.022 & \\
\hline Jarque-Bera & 0.973 & & 0.947 & \\
Breusch-Godfrey & 0.288 & & 0.393 & \\
Breusch-Pagan-Godfrey & 0.786 & & 0.737 & \\
RESET (1) & 0.525 & & 0.484 & \\
RESET $(2)$ & 0.818 & & & \\
\hline
\end{tabular}

Notes: Same as for Table B.2. 
Table B.5: Estimated import demand functions

Dependent Variable: $\Delta \ln M_{t}$

Sample period: 1963-2016 (54 observations)

\begin{tabular}{lccc}
\hline Estimation method & OLS & \multicolumn{2}{c}{ GMM } \\
& & Model 1 & Model 2 \\
\hline Constant & $-0.019^{* *}$ & $-0.023^{* * *}$ & $-0.021^{* * *}$ \\
& $(0.009)$ & $(0.008)$ & $(0.008)$ \\
$\Delta \ln M_{t-1}$ & -0.082 & -0.104 & -0.115 \\
& $(0.081)$ & $(0.073)$ & $(0.073)$ \\
$\Delta \ln Y_{t}$ & $2.721^{* * *}$ & $2.795^{* * *}$ & $2.796^{* * *}$ \\
& $(0.256)$ & $(0.237)$ & $(0.237)$ \\
$\Delta \ln z_{t}$ & $-0.176^{*}$ & $-0.146^{*}$ & -0.138 \\
& $(0.099)$ & $(0.088)$ & $(0.087)$ \\
\hline Long-run coefficients: & & & \\
\hline$\Delta \ln Y$ & $2.514^{* * *}$ & $2.532^{* * *}$ & $2.508^{* * *}$ \\
& {$[99.39]$} & {$[126.54]$} & {$[128.54]$} \\
$\Delta \ln z$ & $-0.163^{*}$ & $-0.132^{*}$ & -0.124 \\
& {$[3.18]$} & {$[2.81]$} & {$[2.51]$} \\
\hline$R^{2}$ & 0.704 & & \\
Adjusted $R^{2}$ & 0.687 & & \\
Schwarz Criterion & -3.587 & & \\
$p$-values for $F$-statistics: & & & \\
\hline Jarque-Bera & 0.409 & & \\
Breusch-Godfrey & 0.592 & & \\
Breusch-Pagan-Godfrey & 0.130 & & \\
RESET (1) & 0.438 & & \\
RESET (2) & 0.121 & & \\
\hline
\end{tabular}

Notes: Same as for Table B.2. 
Table B.6: Estimated unit labor cost equations

Dependent Variable: $\Delta \ln U L C_{t}$

Sample period: $1963-2016$ (54 observations)

\begin{tabular}{lccc}
\hline Estimation method & OLS & \multicolumn{2}{c}{ GMM } \\
& & Model 1 & Model 2 \\
\hline$\Delta \ln U L C_{t-1}$ & $0.363^{* * *}$ & $0.479^{* * *}$ & $0.474^{* * *}$ \\
& $(0.106)$ & $(0.091)$ & $(0.092)$ \\
$\Delta \ln Y_{t}$ & $-0.194^{* * *}$ & $-0.165^{* * *}$ & $-0.146^{* *}$ \\
& $(0.063)$ & $(0.058)$ & $(0.058)$ \\
$\Delta \ln Y_{t-1}$ & $0.404^{* * *}$ & $0.385^{* * *}$ & $0.376^{* * *}$ \\
& $(0.061)$ & $(0.055)$ & $(0.055)$ \\
Inflation expectations $t$ & $0.006^{* * *}$ & $0.005^{* * *}$ & $0.005^{* * *}$ \\
& $(0.001)$ & $(0.001)$ & $(0.001)$ \\
$\Delta$ ln Union activity $t$ & $0.013^{* * *}$ & $0.013^{* * *}$ & $0.012^{* * *}$ \\
& $(0.004)$ & $(0.004)$ & $(0.004)$ \\
1981-2016 Dummy $t$ & $-0.011^{* * *}$ & $-0.010^{* * *}$ & $-0.011^{* * *}$ \\
& $(0.002)$ & $(0.002)$ & $(0.002)$ \\
\hline Long-run coefficients: & & & \\
\hline$\Delta \ln Y$ & $0.329^{* * *}$ & $0.422^{* * *}$ & $0.436^{* * *}$ \\
& {$[9.19]$} & {$[11.19]$} & {$[11.70]$} \\
Inflation expectations & $0.010^{* * *}$ & $0.009^{* * *}$ & $0.009^{* * *}$ \\
& {$[134.46]$} & {$[109.57]$} & {$[110.72]$} \\
$\Delta$ ln Union activity & $0.021^{* *}$ & $0.024^{* * *}$ & $0.023^{* * *}$ \\
& {$[6.22]$} & {$[7.18]$} & {$[6.64]$} \\
1981-2016 Dummy & $-0.017^{* * *}$ & $-0.019^{* * *}$ & $-0.020^{* * *}$ \\
& {$[22.10]$} & {$[23.76]$} & {$[25.25]$} \\
\hline$R^{2}$ & 0.862 & & \\
Adjusted $R^{2}$ & 0.847 & & \\
Schwarz Criterion & -6.179 & & \\
$p$-values for $F$-statistics: & & & \\
\hline Jarque-Bera & 0.473 & & \\
Breusch-Godfrey & 0.854 & & \\
Breusch-Pagan-Godfrey & 0.706 & & \\
RESET (1) & 0.731 & & \\
RESET (2) & 0.911 & & \\
\hline
\end{tabular}

Notes: Same as for Table B.2, except inflation expectations at time $t$ are measured at the end of the previous period and hence are treated as exogenous in the GMM estimation. 
Table B.7: Estimated wage share equations

Dependent Variable: $\Delta \ln \psi_{t}$

Sample period: 1963-2016 (54 observations)

\begin{tabular}{|c|c|c|c|c|}
\hline \multirow[b]{2}{*}{ Estimation method } & \multicolumn{2}{|c|}{ Model 1} & \multicolumn{2}{|c|}{ Model 2} \\
\hline & OLS & GMM & OLS & GMM \\
\hline$\Delta \ln \psi_{t-1}$ & $\begin{array}{c}0.286^{* * *} \\
(0.080)\end{array}$ & $\begin{array}{c}0.285^{* * *} \\
(0.070)\end{array}$ & $\begin{array}{c}0.630 * * * \\
(0.061)\end{array}$ & $\begin{array}{c}0.609^{* * *} \\
(0.052)\end{array}$ \\
\hline$\Delta \ln U L C_{t}$ & $\begin{array}{c}0.372^{* * *} \\
(0.067)\end{array}$ & $\begin{array}{c}0.351^{* * *} \\
(0.059)\end{array}$ & $\begin{array}{c}0.734^{* * *} \\
(0.050)\end{array}$ & $\begin{array}{c}0.676^{* * *} \\
(0.043)\end{array}$ \\
\hline$\Delta \ln U L C_{t-1}$ & $\begin{array}{c}-0.392^{* * *} \\
(0.067)\end{array}$ & $\begin{array}{c}-0.363^{* * *} \\
(0.059)\end{array}$ & $\begin{array}{c}-0.773^{* * *} \\
(0.056)\end{array}$ & $\begin{array}{c}-0.709^{* * *} \\
(0.048)\end{array}$ \\
\hline$\Delta \ln E P_{f_{t}}$ & $\begin{array}{c}-0.023^{* *} \\
(0.010)\end{array}$ & $\begin{array}{c}-0.025^{* * *} \\
(0.009)\end{array}$ & $\begin{array}{l}-0.015 \\
(0.011)\end{array}$ & $\begin{array}{c}-0.012 \\
(0.010)\end{array}$ \\
\hline$\Delta \ln E P_{f_{t-1}}$ & & & $\begin{array}{c}-0.026^{*} \\
(0.013)\end{array}$ & $\begin{array}{c}-0.030^{* * *} \\
(0.011)\end{array}$ \\
\hline$\Delta \ln \mu_{G P M, t}$ & $\begin{array}{c}-0.077^{* * *} \\
(0.014)\end{array}$ & $\begin{array}{c}-0.076^{* * *} \\
(0.012)\end{array}$ & & \\
\hline$\Delta \ln \mu_{A M R, t}$ & & & $\begin{array}{c}-0.098^{* *} \\
(0.047)\end{array}$ & $\begin{array}{c}-0.101^{* *} \\
(0.040)\end{array}$ \\
\hline$\Delta \ln \mu_{A M R, t-1}$ & & & $\begin{array}{c}-0.169^{* * *} \\
(0.053)\end{array}$ & $\begin{array}{c}-0.150^{* * *} \\
(0.044)\end{array}$ \\
\hline$\Delta \ln (\mathrm{SGA} / \text { Sales })_{t}$ & & & $\begin{array}{c}0.077^{* * *} \\
(0.017)\end{array}$ & $\begin{array}{c}0.073^{* * *} \\
(0.015)\end{array}$ \\
\hline$\Delta \ln (\text { SGA/Sales })_{t-1}$ & & & $\begin{array}{c}0.057^{* * *} \\
(0.017)\end{array}$ & $\begin{array}{c}0.055^{* * *} \\
(0.014)\end{array}$ \\
\hline 1982-2016 Dummy $_{t}$ & $\begin{array}{c}-0.004^{* * *} \\
(0.001)\end{array}$ & $\begin{array}{c}-0.004^{* * *} \\
(0.001)\end{array}$ & $\begin{array}{c}-0.003^{* *} \\
(0.001)\end{array}$ & $\begin{array}{c}-0.004^{* * *} \\
(0.001)\end{array}$ \\
\hline 1982-2016 Dummy $_{t} \times \Delta \ln U L C_{t}$ & $\begin{array}{c}0.203^{* * *} \\
(0.065)\end{array}$ & $\begin{array}{c}0.211^{* * *} \\
(0.057)\end{array}$ & $\begin{array}{c}0.188^{* * *} \\
(0.065)\end{array}$ & $\begin{array}{c}0.225^{* * *} \\
(0.055)\end{array}$ \\
\hline 1982-2016 Dummy $_{t-1} \times \Delta \ln U L C_{t-1}$ & $\begin{array}{c}0.040 \\
(0.067)\end{array}$ & $\begin{array}{c}0.024 \\
(0.059)\end{array}$ & $\begin{array}{l}0.119^{*} \\
(0.062)\end{array}$ & $\begin{array}{l}0.093^{*} \\
(0.052)\end{array}$ \\
\hline 1976 Dummy $_{t}$ & $\begin{array}{c}0.014^{* * *} \\
(0.004)\end{array}$ & $\begin{array}{c}0.013^{* * *} \\
(0.004)\end{array}$ & $\begin{array}{c}0.024^{* * *} \\
(0.004)\end{array}$ & $\begin{array}{c}0.024^{* * *} \\
(0.003)\end{array}$ \\
\hline 1989 Dummy $_{t}$ & $\begin{array}{c}-0.014^{* * * *} \\
(0.004)\end{array}$ & $\begin{array}{c}-0.013^{* * *} \\
(0.003)\end{array}$ & & \\
\hline
\end{tabular}

Continued... 
Table B.7, Estimated wage share equations, continued

\begin{tabular}{|c|c|c|c|c|}
\hline \multirow[b]{2}{*}{ Estimation method } & \multicolumn{2}{|c|}{ Model 1} & \multicolumn{2}{|c|}{ Model 2} \\
\hline & OLS & GMM & OLS & GMM \\
\hline \multicolumn{5}{|l|}{ Long-run coefficients: } \\
\hline \multirow[t]{2}{*}{$\Delta \ln U L C$} & -0.028 & -0.017 & -0.104 & -0.085 \\
\hline & {$[1.00]$} & {$[0.48]$} & {$[2.20]$} & {$[2.41]$} \\
\hline \multirow[t]{2}{*}{$\Delta \ln E P_{f}$} & $-0.032^{* *}$ & $-0.035 * * *$ & $-0.110^{* * *}$ & $-0.106^{* * *}$ \\
\hline & {$[4.48]$} & {$[6.90]$} & {$[7.90]$} & {$[11.50]$} \\
\hline \multirow[t]{2}{*}{$\Delta \ln \mu_{G P M}$} & $-0.108^{* * *}$ & $-0.107^{* * *}$ & & \\
\hline & {$[56.05]$} & [69.59] & & \\
\hline \multirow[t]{2}{*}{$\Delta \ln \mu_{A M R}$} & & & $-0.722^{* * *}$ & $-0.642^{* * *}$ \\
\hline & & & {$[8.71]$} & {$[11.59]$} \\
\hline \multirow{2}{*}{$\Delta \ln (\mathrm{SGA} /$ Sales $)$} & & & $0.361^{* * *}$ & $0.329 * * *$ \\
\hline & & & {$[14.78]$} & [19.92] \\
\hline \multirow[t]{2}{*}{ 1982-2016 Dummy } & $-0.005^{* * *}$ & $-0.005^{* * *}$ & $-0.009 * * *$ & $-0.010^{* * *}$ \\
\hline & {$[7.23]$} & {$[9.92]$} & {$[7.28]$} & {$[13.85]$} \\
\hline \multirow[t]{2}{*}{ 1982-2016 Dummy $\times \Delta \ln U L C$} & $0.341^{* * *}$ & $0.329 * * *$ & $0.831^{* * *}$ & $0.816^{* * *}$ \\
\hline & {$[14.57]$} & {$[18.01]$} & {$[18.28]$} & {$[27.92]$} \\
\hline \multirow[t]{2}{*}{1976 Dummy } & $0.020 * * *$ & $0.018^{* * *}$ & $0.066^{* * *}$ & $0.061^{* * *}$ \\
\hline & {$[7.35]$} & {$[8.30]$} & {$[12.20]$} & {$[17.72]$} \\
\hline \multirow[t]{2}{*}{1989 Dummy } & $-0.020^{* * *}$ & $-0.019 * * *$ & & \\
\hline & {$[14.76]$} & {$[17.72]$} & & \\
\hline \multirow[t]{2}{*}{ Total $U L C$ effect in $1982-2016$} & $0.313^{* * *}$ & $0.312^{* * *}$ & $0.727^{* * *}$ & $0.731^{* * *}$ \\
\hline & {$[14.71]$} & [19.08] & {$[18.74]$} & {$[29.16]$} \\
\hline$R^{2}$ & 0.911 & & 0.921 & \\
\hline Adjusted $R^{2}$ & 0.893 & & 0.898 & \\
\hline Schwarz Criterion & -8.030 & & -7.930 & \\
\hline \multicolumn{5}{|l|}{$p$-values for $F$-statistics: } \\
\hline Jarque-Bera & 0.641 & & 0.797 & \\
\hline Breusch-Godfrey & 0.796 & & 0.954 & \\
\hline Breusch-Pagan-Godfrey & 0.133 & & 0.883 & \\
\hline RESET (1) & 0.522 & & 0.496 & \\
\hline RESET (2) & 0.285 & & 0.796 & \\
\hline
\end{tabular}

Notes: Same as for Table B.2, except the total ULC effect in 1982-2016 is the sum of the long-run coefficients on $\Delta \ln U L C$ and 1982-2016 Dummy $\times \Delta \ln U L C$. 